\title{
15 years of service-dominant logic: analyzing citation practices of Vargo and Lusch (2004)
}

\author{
Marco Tregua ${ }^{\circledR}$ \\ Department of Economics, Management, Institutions, \\ University of Naples Federico II, Naples, Italy \\ Danilo Brozovic \\ School of Business, University of Skövde, Skövde, Sweden, and \\ Anna D'Auria \\ Department of Economics, Management, Institutions, \\ University of Naples Federico II, Naples, Italy
}

\begin{abstract}
Purpose - The purpose of this article was to provide an outline of the citation practices of "Evolving to a new dominant logic for marketing" by Vargo and Lusch (2004) to identify and discuss the most prominent research topics in which citations were used and to suggest future research based on the results of the analysis.

Design/methodology/approach - The authors used a comprehensive framework of citation practices based on iterations of previous literature to analyze the relevant literature, which they identified by accessing, systematically and rigorously, every available contribution matching a set of criteria. The authors then categorized these contributions and highlighted the main topics of research interest in each category.

Findings - The findings identify some of the factors in the continuous development of SDL, the way this new marketing logic permeated the scientific debate, the infusion of Vargo and Lusch (2004) into several contributions framed in the new logic or justified through it, and a general perception of a default reference. Additionally, the findings highlight the main topics of research interest in each category.

Research limitations/implications - The analysis enabled the detection of the original paper's influence through advances in service studies, pollination into other fields of research and continuous scientific debate. The authors have highlighted several avenues for research and proposed future research directions.

Originality/value - This research analyzed the effects of the spread of the SDL cornerstone article and emphasized the advantage of using an in-depth approach to the analysis of studies through a framework applied to more than 4,600 studies.
\end{abstract}

Keywords SDL, Citation practices, Service-dominant logic, Service studies, Service theory

Paper type Research paper

\section{Introduction}

Having emerged in the seminal article "Evolving to a new dominant logic for marketing" by Vargo and Lusch (2004), service-dominant logic (SDL) is probably the most relevant development in modern marketing thought. Since the original article, SDL has evolved to consider markets as complex intertwined service ecosystems governed by institutions (Vargo, 2011) and de facto leaning on systems theory (e.g. Barile and Polese, 2010) as much as on Giddens' sociological work (e.g. Edvardsson et al., 2011), combining them within markets and marketing while continually evolving (see Brodie et al., 2019).

(C) Marco Tregua, Danilo Brozovic and Anna D'Auria. Published by Emerald Publishing Limited. This article is published under the Creative Commons Attribution (CC BY 4.0) licence. Anyone may reproduce, distribute, translate and create derivative works of this article (for both commercial and non-commercial purposes), subject to full attribution to the original publication and authors. The full terms of this licence may be seen at http://creativecommons.org/licences/by/4.0/legalcode
15 years of servicedominant logic

Received 6 August 2019

Revised 17 March 2020

14 August 2020

26 December 2020

Accepted 11 February 2021 
JSTP 31,4

Several citation analyses situated within the SDL discourse appeared, aimed at systematizing current knowledge, analyzing existing contributions, identifying central issues and suggesting future research directions, all of which strengthened theoretical advances (as suggested by Light and Pillemer, 1984, and Dresch et al., 2015). For example, Pohlmann and Kaartemo (2017) and da Silva et al. (2018) used a bibliometric co-citation analysis to systematize research in SDL. Also, Wilden et al. (2017) applied co-citation to reveal SDL's interdisciplinary theoretical heritage and significant changes in focal concepts over time. These co-citation and bibliometric approaches have advantages with respect to handling immense datasets, especially in assessing output on the macro level (Haustein and Larivière, 2015). In addition, such approaches have proven suitable for assessing the impact of research within the limits of one particular scientific community, with an emphasis on the journals and countries (Haustein and Larivière, 2015), as exemplified by da Silva et al. (2018). However, they also suffer from several limitations, emphasized by these authors.

A common limitation of co-citation and bibliographic analyses, such as those performed by the colleagues mentioned above, is their limited ability to offer a broader picture beyond a specific field (Haustein and Larivière, 2015). This is because such analyses, from the point of view of citation practice research, tend to neglect the position of the citation in the text, as well as the main reason for citing a certain work (Ding et al., 2014; Zhao and Strotmann, 2014). These aspects are highly relevant to study, especially in terms of citation frequency and context in a text, to improve the analysis results (see also Narin, 1976; Herlach, 1978). Indeed, co-citation analyses tend to treat citations equally, which is another source of critique of these methods, as all citations are not equal (Voos and Dagaev, 1976; Zhao and Strotmann, 2014). For example, using a citation for methodological purposes or to justify research is, logically, more important than listing a citation as one of the many in the literature review. When all citations are treated equally, an analysis may show slightly off-topic results (Khadka and Knoth, 2018).

Against this background, citation practice studies recommend, instead, analyzing the citation context of a reference to provide more detailed and direct information about the nature of a citation (Ding et al., 2014; Liu et al., 2014; Zhao and Strotmann, 2014). Both Pohlmann and Kaartemo (2017) and Wilden et al. (2017) have, in their work, acknowledged reservations about the nature of citations, such as positive and negative sentiments associated with the themes identified, although the former authors attempted to somewhat mitigate this drawback. In addition, citation frequency may be an important indicator with which to measure the influence of a paper, e.g. Vargo and Lusch (2004) have been cited approximately 14,000 times, yet this number itself does not explain why others always cite a certain paper and what influence the paper has (Liu et al., 2015). Citation context analyses provide a more thorough understanding of citing motivations by analyzing different purposes for using a certain citation (Liu et al., 2015). The benefit, according to the authors, is a more nuanced understanding of the impact of the cited work.

To mitigate the above limitations, the focus of our attention in the present article was the citation practices of the original SDL article (Vargo and Lusch, 2004) - a novel approach in analyzing the impact of this article on SDL and on other fields of science in its first 15 years. The article "prompted a paradigmatic shift" (Brodie et al., 2019, p. 3) in marketing studies and was followed by further refinements, advances, and reconfigurations (Vargo and Lusch, 2006, 2008a, b, 2011a, b, 2016, 2017), as well as further expansions proposed by other scholars (e.g. Edvardsson et al., 2011; Wilden et al., 2017). More specifically, our leading research questions address how and why the authors of these approximately 14,000 contributions published in 2018 and earlier used Vargo and Lusch (2004). Granted, focusing the analysis on a single work, although heavily cited, may appear limiting. However, these kinds of investigations are not uncommon within citation practice studies - quite the contrary. For example, we noted the analysis of a Nobel Prize winner's paper (Liu et al., 2015) and of Bourdieu's contribution to 
management and organization studies (Sieweke, 2014). According to these studies, the advantages of such a single-paper approach are that it pinpoints specific contributions of a single work, both to its main field and to other related and unrelated fields; assesses how comprehensive these contributions are; and provides a richer understanding of which knowledge claims present in a single paper have had the greatest impact on later works.

In addition to these advantages, while we acknowledge the evolution of SDL (Brodie et al., 2019), we simultaneously recognize four contributions of Vargo and Lusch (2004) that remain pivotal throughout this evolution. Namely, value-in-use is still a vital concept, despite new and accompanying conceptualizations of value (e.g. value-in-context, value-in-experience), which can be seen in many recent articles (e.g. Jayashankar et al., 2018; Jang et al., 2020). Second, value proposition is still central to expressing how firms and customers interact (Payne et al., 2020). Third, the distinction between operand and operant resources and how resource integration impacts value co-creation is still critical (Ghatak, 2020). Finally, Vargo and Lusch's (2004) contribution to developing an alternative perspective on marketing and markets adopting a socioeconomic view is constantly being accentuated (Brodie et al., 2019; Liu et al., 2020).

Unlike previous citation analyses studies regarding SDL, our research adds more nuance; namely, we provided patterns of the citation practices of Vargo and Lusch (2004) and charted how it received such an imposing spread in marketing and other literature. We added another aspect to previous analyses by differentiating among multiple reasons for citations (as emphasized by Aya et al., 2005) and by focusing on analyzing the context of the citations, as defined by Bornmann and Daniel (2008). We also highlighted topics of research interest within the patterns of citation practices grouped into categories, and we suggested future research directions based on the categories and topics. These noticeable research topics may be understood as distinct contexts in which the general theory meets practice and where they influence each other; in other words, these topics can be considered as midrange theories (Vargo and Lusch, 2017; Brodie and Peters, 2020) that have the potential to further drive the development of SDL while simultaneously contributing to their own respective fields. Thus, our purpose was to provide an outline of the citation practices of "Evolving to a new dominant logic for marketing" by Vargo and Lusch (2004) (henceforth: V\&L04), to identify and discuss the most prominent research topics in which the citation was used and to suggest future research based on the results of the analysis.

We achieved this purpose by developing a comprehensive framework of citation practices based on our iterations of previous literature in citation practices and developed a set of criteria to choose relevant contributions out of the approximately 14,000 contributions in Google Scholar. Thus, we chose contributions that were written in English and published as academic journal articles, book chapters, and books. In every such contribution, we identified the metadata, the citations of V\&L04, and the field of research; we also assessed each citation's context and determined the main reason for the citation. We repeated the process for 4,612 contributions published between 2004 and 2018, systematized and presented our findings in terms of citation practices and a research agenda, and closed the article with theoretical implications and future research directions.

Our contribution is threefold. First, we are contributing to SDL, service research, and marketing by providing a more nuanced analysis of the citation practices of V\&L04 and by discussing the theoretical consequences of the citation practices of V\&L04. Second, we have proposed future research based on the analysis, as well as on the highlighted topics emerging from the analysis and calling for further scholarly efforts. Third, we are contributing to citation practice research by having developed a novel and comprehensive framework of citation practices, synthesizing the frameworks of citation practice used in the past 50 years, from Garfield (1965) to Tahamtan and Bornmann (2018), and applying it more extensively as compared to previous citation practice analyses. Ultimately, researching citation practices in
15 years of servicedominant logic 
JSTP 31,4 a more differentiated manner creates a better understanding of scholarly communication (Aya et al., 2005), in our case, within SDL, service studies and marketing.

\section{Research process and methodological tools}

Research premises: SDL and its development

The development of SDL represents the basis for our research, as well as the context in which the citation practices of V\&L04 and the associated research topics emerged and developed. We briefly describe this basis and the context of our research by presenting the most significant advances in SDL.

SDL emerged in the seminal article V\&L04 as a novel perspective that conceptualized service as the basis of all exchange and conceptualized customers as co-creators (originally co-producers) of value. The authors originally established 8 SDL Foundational Premises (FPs); the paper received the AMA Maynard Award and has been the most cited article in the Journal of Marketing since 2000.

Vargo and Lusch did not offer a finished theory, but initiated a research stream and a worldwide community as an open platform. Thus, the first significant movement in SDL (besides the Otago Forum 2005) happened in 2006 with the book - including advances from about 50 scholars - The Service-Dominant Logic of Marketing: Dialog, Debate, and Directions (Lusch and Vargo, 2006a) and the article "Service-dominant logic: reactions, reflections, and refinements" (Lusch and Vargo, 2006b).

The next significant movement occurred in 2008 (Brodie et al., 2019) with the Journal of the Academy of Marketing Science's special issue "Service-dominant logic: continuing the dialogue," in which the other seminal article, "Service-dominant logic: Continuing the evolution," was published, along with "Why "service'?" (Vargo and Lusch, 2008a). The former updated the FPs and discussed the direction of future work, while the latter clarified the concept of service as the essence of value co-creation, exchange and marketing.

Also, the Forum on Markets and Marketing has been held biennially since 2008, aimed at advancing SDL by focusing on foundational issues related to markets and marketing (FMM, 2018). Since 2009, the Naples Forum on Service has been held as a biennial conference resting on three pillars: SDL, service science, and network and systems theory. The SDL community continued to grow, and several advances have appeared (further details are offered in Table 1), along with the Handbook of Service Science (Maglio et al., 2010) and "Servicedominant logic: a necessary step" (Lusch and Vargo, 2011).

New significant advancements took place upon the introduction of value-in-context (Chandler and Vargo, 2011) and the infusion of systems theory, the propelling service ecosystems perspective, and the introduction of institutions (Vargo and Lusch, 2011a, Vargo, 2011; Edvardsson et al., 2011; Mars et al., 2012; Vargo and Akaka, 2012; Wieland et al., 2012; Akaka and Vargo, 2015; Akaka et al., 2015; Lusch and Nambisan, 2015; Vargo et al., 2015).

Vargo and Lusch (2016) further clarified SDL's narrative and process and updated FPs to axioms. Furthermore, in "Service-dominant logic 2025" (Vargo and Lusch, 2017), the authors suggested new research. The latest significant advancement is the SAGE Handbook of Service-Dominant Logic (Vargo and Lusch, 2018), covering the reactions to SDL's core concepts by approximately 70 scholars. Table 1 summarizes these main advances of SDL.

\section{Research aim and methodological approach}

Following our purpose - to provide an outline of the citation practices of V\&L04 so as to identify and discuss the most prominent research topics in which the citation was used and suggest future research based on the results of the analysis - we designed our research process in four steps: (1) establishing the elements of the analysis - setting citation practices as a way to 


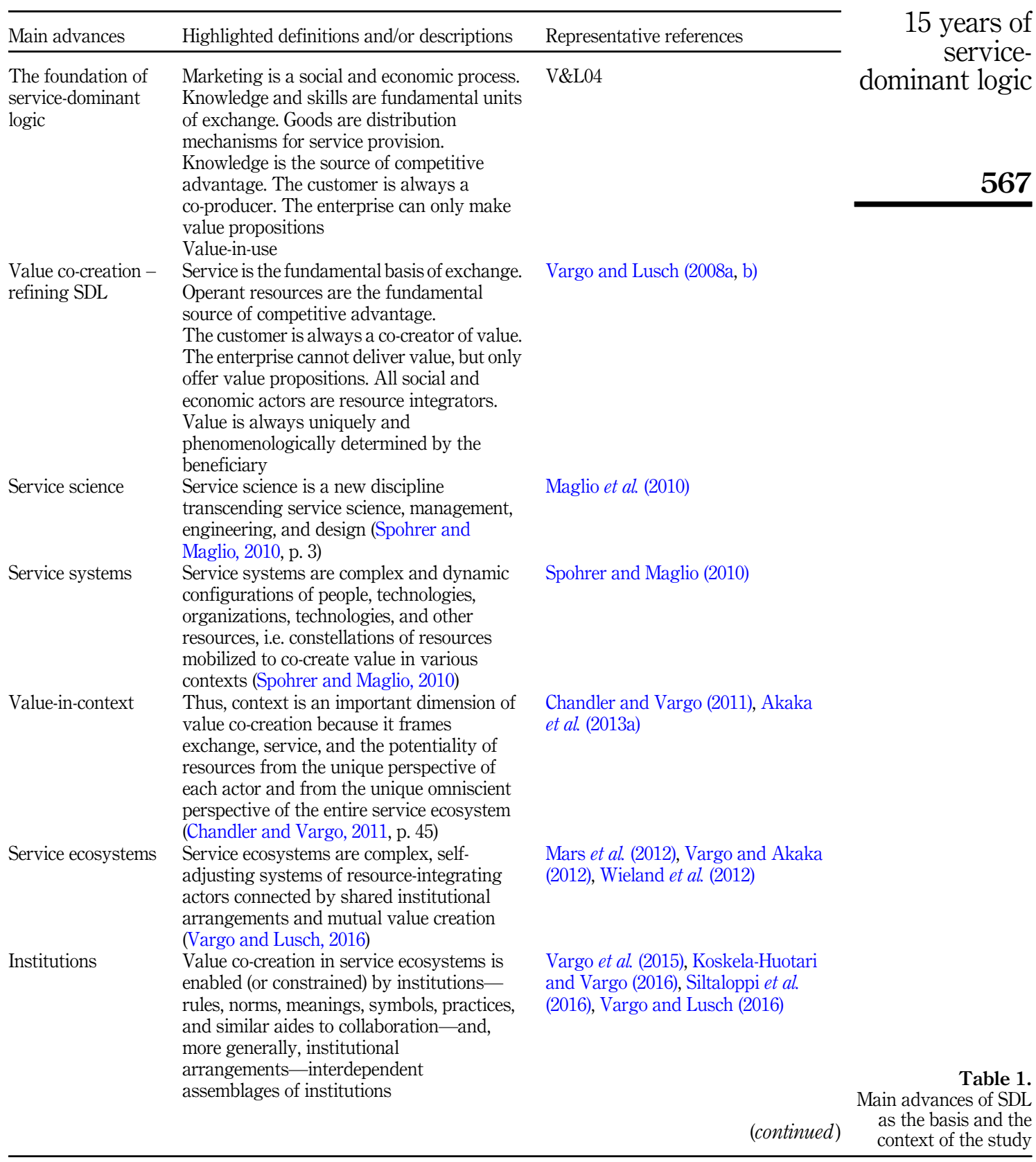


JSTP

31,4

\begin{tabular}{lll}
\hline Main advances & Highlighted definitions and/or descriptions & Representative references \\
\hline $\begin{array}{l}\text { The narrative of } \\
\text { SDL }\end{array}$ & $\begin{array}{l}\text { Actors are involved in resource integration } \\
\text { and service exchange, enabled and }\end{array}$ & Vargo and Lusch (2016, 2017)
\end{tabular}

SDL and service exchange, enabled and

constrained by endogenously generated

institutions and institutional arrangements,

\section{8}

Axioms of SDL establishing nested and interlocked service ecosystems, within which actors co-create value

(1) The application of specialized skills and knowledge is the fundamental unit of exchange

(2) Value is co-created by multiple actors, always including the beneficiary

(3) All social and economic actors are resource integrators

(4) Value is always uniquely and phenomenologically determined by the beneficiary

(5) Value co-creation is coordinated through actor-generated institutions and institutional arrangements

SDL 2025: Future Mid-range theories should be developed to research agenda partner with SDL development as a theory of markets. The authors proposed a wide and structured research agenda for marketing and other fields

Charting the field: The SDL Eleven themes were grouped as the most Handbook insightful advances in SDL and stimulated a debate on theoretical developments, empirical advances and future research

Table 1. directions

Vargo and Lusch (2017)

Vargo and Lusch (2018)
Vargo and Lusch (2016) 
The category "Propagate a theory" combines previous practices of debating, i.e. discussing the cited paper (Hernández-Álvarez et al., 2016); comparing, contrasting, and criticizing it (Aya et al., 2005); offering negational and critical views (Bornmann and Daniel, 2008; Tahamtan and Bornmann, 2018); and considering the practices of theory, concept, definition, and argument by White and Wang (1997), integrated with Aya et al.'s (2005) extending practice.

The "Position a contribution" category is an iterative amalgam of the following citation practices: theory/concept/definition/argument and justification (White and Wang, 1997), affirmational and assumptive (Bornmann and Daniel, 2008; Tahamtan and Bornmann, 2018), and establishing the legitimacy of the topic and reviewing prior work in the field (Case and Higgins, 2000).

The last category, "Default citation practices" combines default practices (Aya et al., 2005) and the practices of paying homage (Aya et al., 2005; Garfield, 1965, in Smith, 1981) with ceremonial citation practices and identification of the originator (White and Wang, 1997), citing a recognized authority in the field (Case and Higgins, 2000) and mentioning it in passing (Hernández-Álvarez et al., 2016).

Table 2 shows an overview of how we combined and derived our framework of citation practices. Essentially, we built on previous understandings of the most common practices and aligned them with the purpose of our research.

\section{Step 2 - Identifying the criteria of the analysis}

The number of contributions aligned with the criteria set is summarized in Figure 1. First, the analysis was centered on publications written in English. Second, the number of

\begin{tabular}{|c|c|c|}
\hline & Category & Matching previous frameworks \\
\hline 1 & $\begin{array}{l}\text { Advance a field of } \\
\text { studies }\end{array}$ & $\begin{array}{l}\text { Extending citation practices (Aya et al., 2005) combined with self-citation, } \\
\text { correcting one’s own/others' work (Garfield, 1965, in Smith, 1981), corroboration } \\
\text { (Hernández-Álvarez et al., 2016), usage of concepts (Bornmann and Daniel, 2008; } \\
\text { Hernández-Álvarez et al., 2016), and contrast (Aya et al., 2005; Bornmann and } \\
\text { Daniel, 2008; Hernández-Álvarez et al., 2016) }\end{array}$ \\
\hline 2 & Propagate a theory & $\begin{array}{l}\text { Citation practices of debate (Hernández-Álvarez et al., 2016), compare, contrast, } \\
\text { and criticize (Aya et al., 2005), negate and criticize (Bornmann and Daniel, 2008; } \\
\text { Tahamtan and Bornmann, 2018), disclaim the work or ideas of others (negative } \\
\text { claims), dispute the priority claims of others (negative homage) (Garfield, 1965, in } \\
\text { Smith, 1981), point out weaknesses (Hernández-Álvarez et al., 2016), combine a } \\
\text { theory/concept/definition (White and Wang, 1997) to extend it (Aya et al., 2005), } \\
\text { mark a particular concept (Case and Higgins, 2000) and its usage (Bornmann and } \\
\text { Daniel, 2008; Hernández-Alvarez et al., 2016), review prior work to extend in the } \\
\text { area (Case and Higgins, 2000; Aya et al., 2005), and alert/encourage forthcoming } \\
\text { work (Garfield, 1965, in Smith, 1981) }\end{array}$ \\
\hline 3 & $\begin{array}{l}\text { Position a } \\
\text { contribution }\end{array}$ & $\begin{array}{l}\text { Iterative amalgam of several citation practices: justification (White and Wang, } \\
\text { 1997); establishing the legitimacy of the topic (Case and Higgins, 2000) combined } \\
\text { with citing to mark a particular concept (Case and Higgins, 2000); reviewing prior } \\
\text { work in the field (Case and Higgins, 2000), even work that is affirmational and } \\
\text { assumptive (Bornmann and Daniel, 2008; Tahamtan and Bornmann, 2018); and } \\
\text { substantiating claims (Garfield, 1965, in Smith, 1981) }\end{array}$ \\
\hline 4 & $\begin{array}{l}\text { Other citation } \\
\text { practices }\end{array}$ & $\begin{array}{l}\text { Citation practices of ceremony (White and Wang, 1997), paying homage (Aya } \\
\text { et al., 2005), being perfunctory and persuasive (Bornmann and Daniel, 2008), } \\
\text { identifying the originator (White and Wang, 1997) or the original publication } \\
\text { describing an eponymic concept (Garfield, 1965, in Smith, 1981), acknowledging a } \\
\text { recognized authority in a field (Case and Higgins, 2000), and mentioning it in } \\
\text { passing (Hernández-Alvarez et al., 2016) }\end{array}$ \\
\hline
\end{tabular}

15 years of servicedominant logic 
JSTP
31,4

570

Figure 1.

Criteria of analysis
TOTAL NUMBER OF CITATIONS COUNTED BY GOOGLE SCHOLAR (2004 - 2018)

13,096

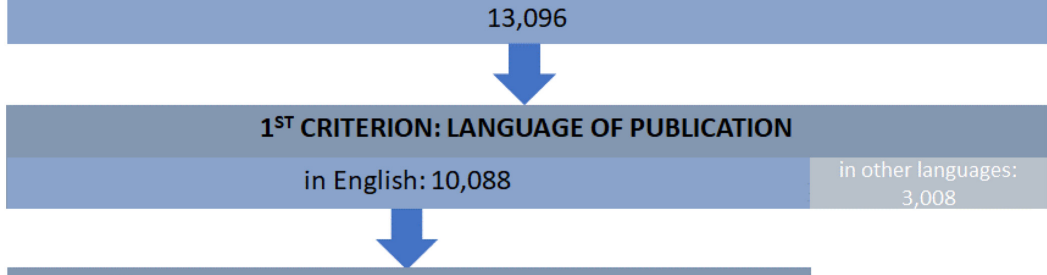

$2^{\text {ND }}$ CRITERION: AVAILABILITY ON GOOGLE SCHOLAR

Available: 9,587

$3^{\text {RD }}$ CRITERION: RELEVANT CONTRIBUTIONS

Books, chapters and papers in academic journals: Dissertations, working papers, proceedings 5,006

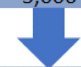

\section{$4^{\text {TH }}$ CRITERION: ACCESSIBILITY}

not restricted access: $\quad 4,692$

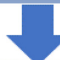

FINAL DATASET

actually citing V\&L04: 4,612

contributions actually available on Google Scholar is lower than what the query showed. Discrepancies in count - even if limited to less than 3\% - emerged for every year except 2004. Third, only articles in academic journals, chapters, or entire books were considered, without excluding any research area or journal. Other types of contributions (proceedings, working papers, and dissertations) were discarded. Fourth, due to restricted access, we were unable to download all the contributions citing V\&L04, although we accessed the databases from several universities in different countries. These cases represent about $6 \%$ of the entire dataset. Finally, 80 contributions were discarded because they did not actually cite V\&L04, but other papers by Vargo and Lusch. The final data set included 4,612 contributions.

\section{Step 3 - Data collection}

We collected the contributions, assigning part of the entire set of contributions to each author. Our aim was to achieve an equal and homogeneous analysis. To that end, online shared folders were used for 1.5 years Table 3 offers an overview of the data collected according to the year of publication.

\section{Step 4 - Labeling, fine-tuning and analysis}

The analysis proceeded continuously for 1.5 years. The debate over the categories' content and labeling continued during the analysis. We analyzed contributions that had unclear classifications with respect to some elements - in most cases, the reason for citing V\&L04 - to compare views, resolve doubts, and reach an agreement about the outcome. This led to continual weekly online meetings to compare the preliminary results and fine-tune the 


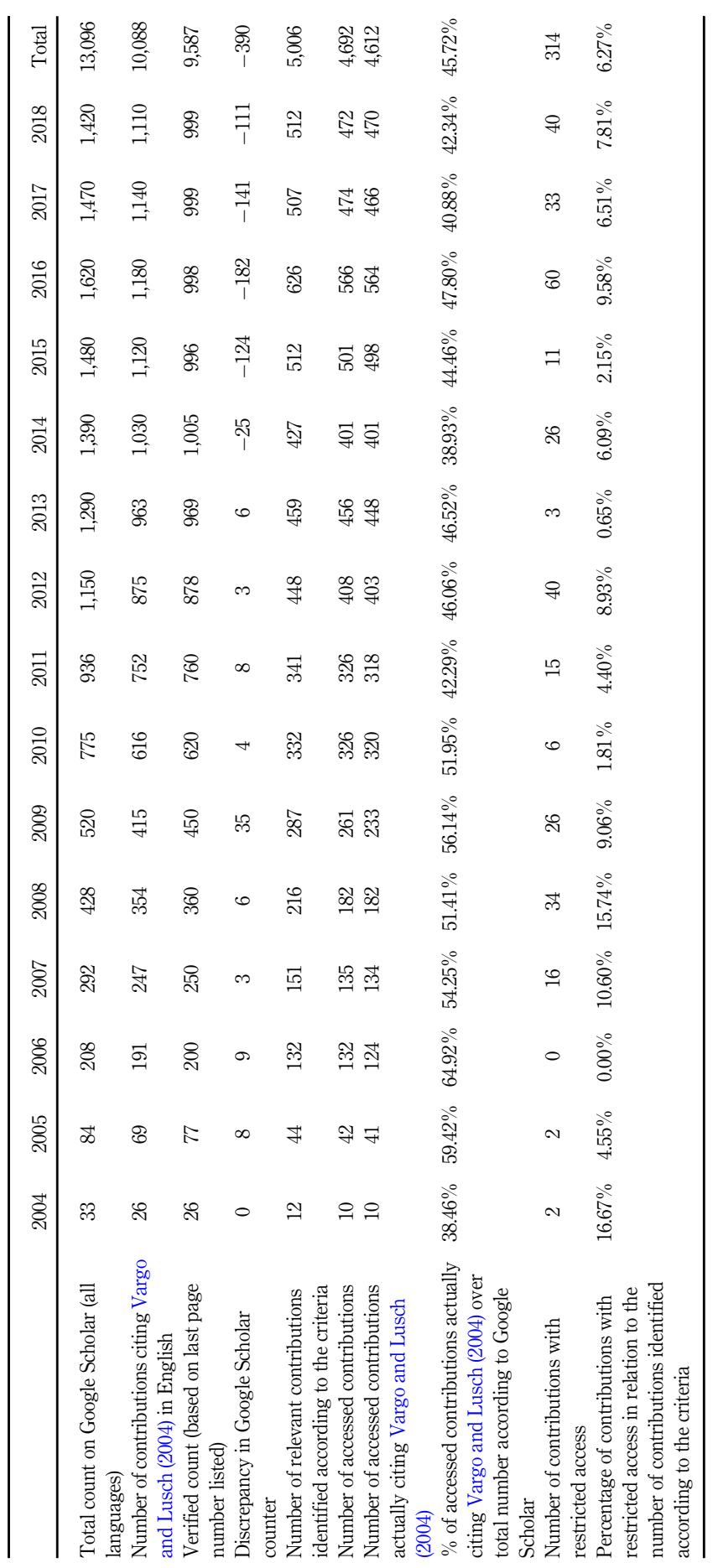

15 years of servicedominant logic

571
Table 3.

Key features of data collection divided 
JSTP 31,4 categories until we had achieved a solid set of alternatives useful for classifying the whole dataset and avoiding overlaps.

It is worth noting that the contributions were categorized based on the main reason to cite, as we recognized that, in some cases, more than one reason to recall V\&L04 arose within a single publication. In such cases, we listed citation practices, recognized the most dominant one, and confirmed it by matching it to the contribution's purpose. In the most dubious cases, we consulted each other during our sessions and collectively reached an agreement about the main citation practice. An illustration of this methodological concern is the article by Dong (2015), in which we recognized several citation practices. In the introduction of Dong (2015), the author acknowledged the general paradigm shift in marketing ("Default citation") and essentially framed the paper using V\&L04 ("Framing the contribution"); later, she included an interpretation of some of the postulates of V\&L04 in her literature review. As the latter citation practice is dominant, the article was categorized under "Literature review."

Another important methodological consideration is that our analysis focused solely on V\&L04 and not on any of the other articles advancing SDL. This clarification is relevant because, for example, even if the purpose and general intention of contributions citing V\&L04 coincided with categories such as "Advance SDL" or "Justify an element of research" (which is how the overall SDL contributions would be used in such a contribution), V\&L04 itself can be merely mentioned and the article cited more generally, e.g. as "A default citation." One example is Nenonen and Storbacka (2010), who overall leaned heavily on Vargo and Lusch (2008a) and SDL as the perspective from which they designated business models as interactive co-creations. Yet V\&L04 is mentioned a couple of times in more general terms, which is why we interpreted the citation practice in this article as "A default citation."

Furthermore, in our citation analysis, we adopted the context analysis approach, which Bornmann and Daniel (2008) described as an analysis scrutinizing the context of citations in citing documents by devising a classification of the text surrounding the citation and requiring that the citing publication be read to determine the citation context. Indeed, the context of the citation "contains the direct related information between cited paper and citing paper" (Liu et al., 2015, p. 242), which makes it the most suitable way to perceive the way a contribution used V\&L04. When a single article is cited substantially, the undertaking can be massive (see also McCain and Turner, 1989). Although novel in SDL, the context analysis approach is a well-established method in various research fields; in addition to several studies that Bornmann and Daniel (2008) reviewed, we noted a citation context analysis of a Nobel Prize winner's paper (Liu et al., 2015), an analysis of Bourdieu's contribution to management and organization studies (Sieweke, 2014), and the use of citation context analysis in literature recommendations (Doslu and Bingol, 2016). Although more recent citation context analyses are performed with machines and advanced algorithms, we opted for the rather traditional albeit time-consuming - and in-depth approach that Bornmann and Daniel (2008) advocated, in which the citation's context must be read to be understood. However helpful they may be, machines have not yet reached the level of understanding required to perform such analyses.

The process described above led to the categories proposed in Table 4; additionally, Table 4 describes the labeling of categories and sub-categories and the intended reason for citing V\&L04. It also provides an example for each category as both a clarification of, and an excerpt from, the analysis.

\section{Findings}

The following section presents our findings. First, we have broken down the results of the analysis in graphical representations. Figure 2 presents the visual breakdown of the number of contributions per each main category of citation practice, along with the most significant movements of SDL. Table 5 offers quantitative breakdowns of the categories and sub- 


\begin{tabular}{lll}
\hline & Category & Intended meaning \\
\hline 1 & $\begin{array}{l}\text { Advance service } \\
\text { studies } \\
\text { Strictly advance } \\
\text { service studies }\end{array}$ & $\begin{array}{l}\text { Contributions citing Vargo and Lusch (2004) } \\
\text { to advance service studies } \\
\text { Contributions using Vargo and Lusch (2004) } \\
\text { to advance service research in general, } \\
\text { without focusing on a particular perspective }\end{array}$ \\
1.1 & Advance SDL & $\begin{array}{l}\text { Contributions using Vargo and Lusch (2004) } \\
\text { to advance SDL (NB: This is a parent category } \\
\text { only) } \\
\text { Includes advances in SDL authored by Vargo } \\
\text { and Lusch (either by both of them or by both } \\
\text { of them together with other authors) or } \\
\text { contributions authored by only Vargo or } \\
\text { Lusch }\end{array}$ \\
& Self-advance &
\end{tabular}
1.1.2 Conceptual Includes conceptual advances in SDL by advances by other other authors, but also by Vargo or Lusch authors with other authors

1.1.3 Empirical advances by other authors

Includes empirical advances in SDL by other authors, but also by Vargo or Lusch with other authors

\subsection{Advance contrasting perspectives}
1.3 Advance other perspectives

Representative examples

\section{5 years of service- dominant logic}

"The service logic or service-dominant logic make the active role of the consumer, and thus the impact of communication, even more significant (Grönroos, 2008; Payne et al., 2008; Vargo and Lusch, 2004, 2008a, b)" (Holmqvist and Grönroos, 2012, p. 430)

"As we have further discussed and elaborated our view of S-D logic since 'Evolving. ..' (Vargo and Lusch, 2004) was published, we have caught and corrected some of the more critical lexicographic slips that had become apparent" (Vargo and Lusch, 2008a, p. 2)

"The dominant logic of marketing is shifting from a firm-centric view of value creation to one that examines how customers engage themselves in the value-creation process (Prahalad and Ramaswamy, 2003; Vargo and Lusch, 2004). The goal of this chapter is to advance a model that is better suited to dialectical value creation and a customercentric orientation of the firm" (Arnould et al., 2006, p. 91)

"According to Vargo and Lusch (2004), the value of an experiential service can only be determined by the user in the 'consumption' of the service; however, the findings of the present study would suggest that, in the case of 'test drives', some value is derived from the pre-service experience of the 'test drive'. The customer appears to infer a certain potential value that might subsequently be obtained from the 'real' service experience. The present study suggests that this potential value could be referred to as value in pre-use" (Edvardsson et al., 2010, p. 321) "CDL takes an entirely different focus on customers [...]. SDL is systems dominant with generic actors (Vargo and Lusch, 2004 Lusch and Vargo, 2014), while SL is focused on the dyadic process of value co-creation and the interaction between the provider and the customer (Grönroos, 2006,- Grönroos and Gummerus, 2014)" (Heinonen and Strandvik, 2015, pp. 474-475)

"Overall then, this first step in our proposed framework, at the system level, acknowledges that service implies systemic processes; the most recent service views, such as the service-dominant logic (SDL; Vargo and Lusch, 2004), appear intrinsically oriented toward systems thinking. The VSA makes this orientation explicit and builds on its implications, highlighting implications for service research" (Barile et al., 2016, p. 657)
Table 4.

Breakdown of categories and subrepresentative categories with 


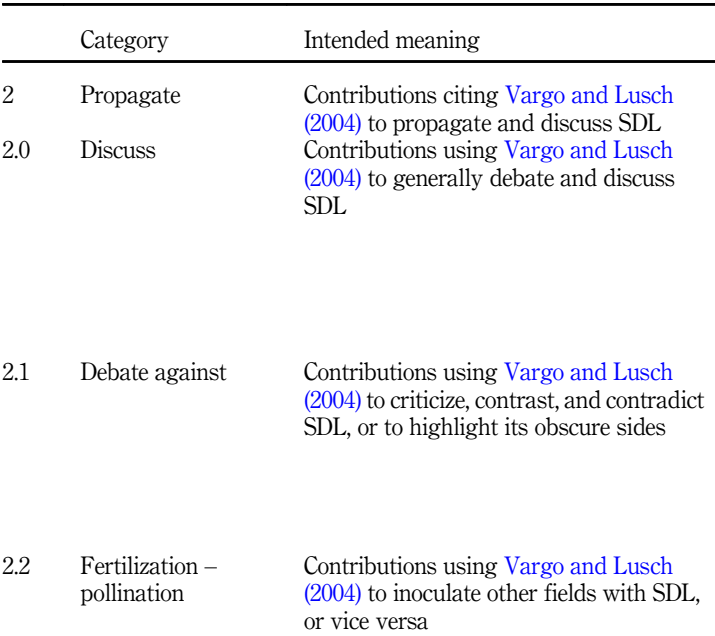

Representative examples

31,4 or vice versa

2.3 Set research agenda

3 Position

3.0 Positioning
Contributions using Vargo and Lusch (2004) to propose research agendas, not exclusively within SDL

Contributions citing Vargo and Lusch (2004) to position the contribution Contributions using Vargo and Lusch (2004) to generally position the contribution
"The emerging dominant logic has many implications, but they are not entirely the ones that V \&L have in mind. Vargo and Lusch believe that marketing should be at the center of the integration and coordination of the crossfunctional processes of a service-centered business model, but this depends on what is meant by "marketing." (Day et al., 2004, p. 19) "Our first criticism lies in the definition of services 'as the application of specialized competences (knowledge and skills) through deeds, processes, and performances for the benefit of another entity or the entity itself (Vargo and Lusch, 2004, p. 2)" (O'Shaugnessy and O'Shaugnessy, 2009, p. 785)

"The unfavourable experience that is outside the customers' normal experience must be understood as being beyond the boundary of what is acceptable or within the range of objectionability. The basis of this understanding can be found in adaptation-level theory, prospect theory and social-judgement theory (for more discussions, see, e.g. Sherif et al., 1965; Kahneman and Tversky, 1979; Vargo and Lusch, 2004; Tronvoll, 2007)" (Tronvoll, 2012, p. 290)

"Vargo and Lusch (2004) offer a new dominant logic for marketing that is better suited for today's service economy than is the traditional model of exchange adapted from economics. The traditional model of exchange is based on manufactured, tangible resources with embedded value that are exchanged between buyer and seller via transactions. The new paradigm in marketing incorporates intangible resources whose value is co-created by both buyer and seller through relationships, not exchange. The differences between a contemporary view of marketing that better reflects the 'new economy' and the historical economic approach pose challenges when applying lean principles to a sales engagement versus a manufacturing setting" (Barber and Tietje, 2008, p. 157)

"There have been many developments and research streams within the customer perceived value domain. One of the most recent conceptualizations, drawing from the servicedominant logic (Lusch and Vargo, 2011; Vargo and Lusch, 2004, 2008a), is value co-creation (Payne et al., 2008)" (Arslanagic-Kalajdzic and Zabkar, 2015, p. 88) 


\begin{tabular}{lll}
\hline & Category & Intended meaning \\
\hline 3.1 & Literature review & $\begin{array}{l}\text { Contributions whose literature reviews } \\
\text { are mainly, but not always solely, based } \\
\text { on Vargo and Lusch (2004) and SDL }\end{array}$
\end{tabular}

3.2 Framing the contribution

3.3 Justify an element of the research

4 Default citations

4.1 Paying homage to the originators
Contributions using Vargo and Lusch (2004) to frame the perspective on the contribution

Contributions using Vargo and Lusch (2004) to justify one or some elements of the research, e.g. part(s) of the research framework, the purpose, or the discussion

Contributions citing Vargo and Lusch (2004) for other purposes

Contributions using Vargo and Lusch (2004) to explicitly pay homage to the article or recognize its seminal role

Contributions referring to Vargo and Lusch (2004) in broad, general terms
Representative examples

"Vargo and Lusch $(2004,2006)$ extended these conceptions of the value-delivery sequence by involving the customer as a co-creator of value, with the role of firm being reduced to that of a 'value proposition maker'. Other recent studies have also argued for the importance of the proactive involvement of customers in the valuecreation process (Prahalad and Ramaswamy, 2004; Payne, 2006; Grönroos, 2006)" (Mele, 2007, p. 244, within literature review as its significant part)

"Despite these contributions important research gaps remain, in particular with respect to the conceptual association of CE vis-à-vis other theoretical entities, including service dominant (S-D) logic and its associated lexicon (Vargo and Lusch, 2004, 2008a, 2016), thus limiting our understanding of $\mathrm{CE}$ and its theoretical interconnections" (Hollebeek et al., 2019, p. 2)

"In sum, learning, publicity and compatibility belong to the intangible operant resources, echoing what Vargo and Lusch (2004) famously pronounced, 'resources are not; they become' (p. 2). As the factor that contributed to the highest amount of variance $(19 \%), F 1$ connotes a palpable relational and long-term emphasis as a paramount BPS dimension" (Lee et al., 2010,

p. 611; justifying an element of their findings)

"The catalyst for this interest has been the publication of an award-winning article by Vargo and Lusch in the Journal of Marketing (2004) entitled 'Evolving to a New Dominant Logic for Marketing"' (Aitken et al., 2006, p. 275)

"Business literature now proposes that customers 'co-create value' with companies (Payne et al., 2009; Tynan and McKechnie, 2009; Prahalad and Ramaswamy, 2004; Vargo and Lusch, 2004), while current cultural policy locates value in the public's estimation of culture” (Rumbold, 2010, pp. 314-315)

\section{5 years of service- dominant logic}

Table 4.

categories per year, represented in numbers and percentages. Table 6 breaks down the methodological approaches of the contributions identified.

Second, we classified the findings according to the four main categories of citation practices: "Advance service studies," "Propagate," "Position," and "Default citations." In each category, we presented the general trends and main fields of impact. We continued by focusing on the trends, fields and methodological approaches in the associated subcategories. The findings for each category conclude with a short summary emphasizing the main insights of the analysis.

\section{Category 1 - Advance service studies}

The first category, "Advance service studies," contains a higher number of sub-categories as compared to other categories, due to the need to clarify different views in service research and to present how scholars used V\&L04. The main research topics emerging in this category are conceptualizations of value, the role of employees in value co-creation, the context of the value 
JSTP

\section{6}

Figure 2 .

V\&L04 citation practices and trends and the most significant advances of SDL

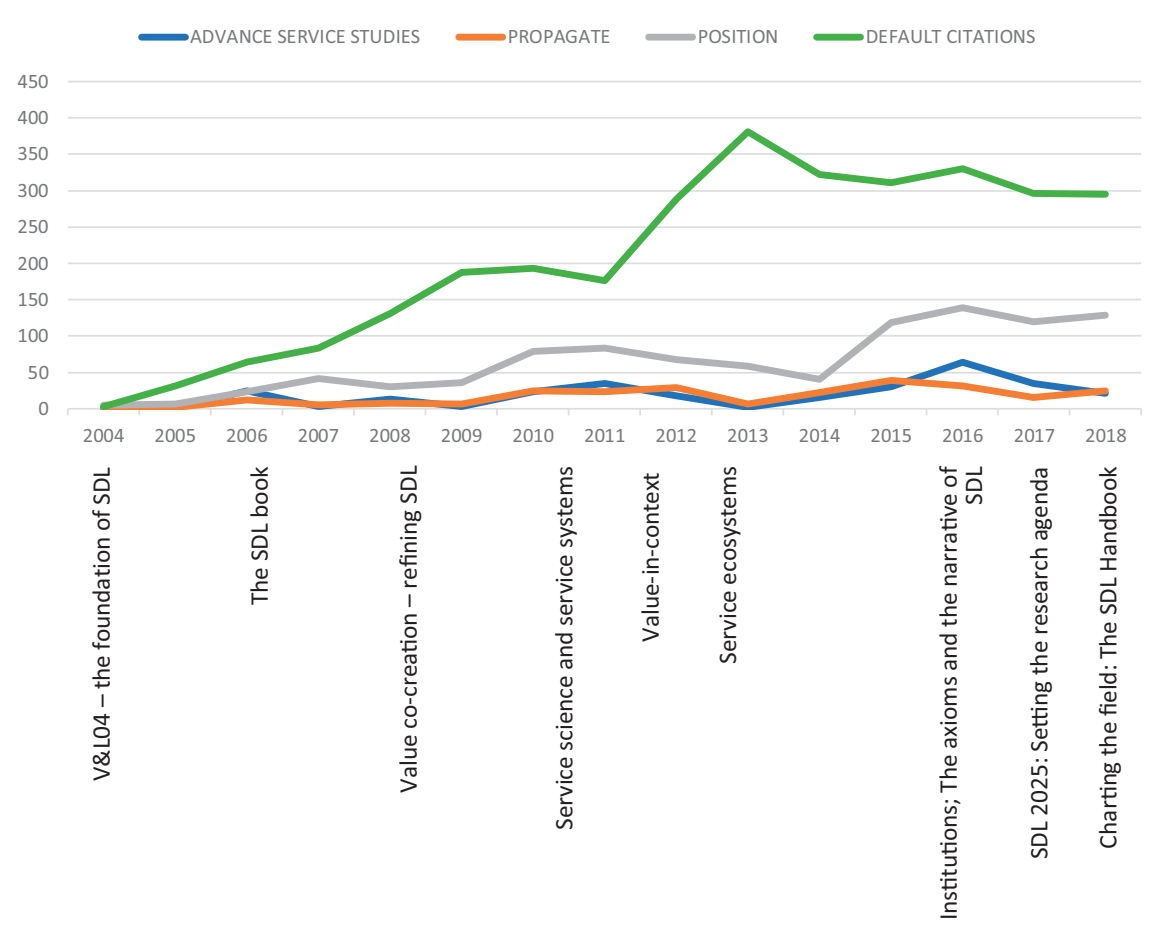

co-creation process, the theoretical evolution of SDL, and the role of the new consumer groups.

The citations in Category 1 represent a very limited portion of the entire dataset, with 290 contributions out of 4,612 , i.e. $6.65 \%$ (see Table 5). This category mainly considers furthering service studies, as in Jaakkola et al. (2015), for example, who focused on service experience; conceptualized it, starting from V\&L04; and offered avenues for further research.

In addition, the analysis highlights conceptualizations of value as one main topic, starting with V\&L04 distinguishing value-in-exchange from value-in-use, which led to considering conceptualizations and configurations of value from other perspectives, such as service systems (see Vargo et al., 2008). Other conceptualizations of value have subsequently been considered, for example, value-in-context (Chandler and Vargo, 2011) and the aforementioned value-in-experience by Jaakkola et al. (2015). Interest in this topic does not seem to abate; for example, Makkonen and Olkkonen (2017) recently analyzed the interchange among value-inuse, value-in-context and value-no-creation (situations in which value is not created), while Ranjan and Read (2016) - in a literature review on the concept of value co-creation - recalled value-in-use from V\&L04 and gave evidence of the role of customers in use, with effects on value propositions. The discourse on the conceptualizations of value is centered on value-inuse as one firmly remaining concept from V\&L04 and how other elements, such as the context, experience and social features, affect it.

The trends tendency in Category 1 is quite stable, apart from two sub-categories assuming different and interesting conduct, specifically, "Conceptual advances by other authors" and "Empirical advances by other authors." The former adopts a regular tendency with a main peak every five years: 2006, 2011, and 2016. On the other hand, "Empirical advances by other authors" first appears in 2010, maintains a low number of occurrences until 2015, and then 
undergoes a notable peak (the highest for the entire category) in 2016, with a total of $5.32 \%$, before decreasing again in 2017 and 2018. One example of empirical advances was Xu et al. (2014), who described how co-creation can occur in service recovery and the role employees may have in supporting this process. The role of employees in value co-creation is a topic that occupied many contributions in this sub-category, regarding both conceptual and empirical advances. Besides Xu et al. (2014) and Neghina et al. (2015) conceptualized the collaborative side of value co-creation through the dimensions of employee-customer interactions. Moreover, Karpen et al. (2015) contributed to research on this topic to empirically identify how employees in touch with customers may either favor or hinder value creation. More recently, the role of employees in value co-creation was explored in light of interactions between service robots and users (e.g. Wirtz et al., 2018). Consequently, more research into the role of employees on value co-creation is expected.

Empirical advances are particularly important in translating the abstract nature of SDL to a more practical, applicable level, making it more managerially relevant (Brodie and Peters, 2020). For example, Karpen and colleagues (Karpen et al., 2012, 2015), with their servicedominant orientation (SDO), linked SDL and strategic business practice; Brodie et al. (2013) explored customer engagement in a virtual brand community; and Jakkola and Alexander (2014) conducted a case study analysis of customer engagement behavior in value co-creation within a public transport service system.

The observed peaks of the entire category (see Figure 2) correspond with (or have been forerun by) some calls for research concerning SDL, such as a special issue on "Evolving a new dominant logic" in the Journal of the Academy of Marketing Science (2006), the chapter published by Vargo et al. (2010) on "Advancing service science with service-dominant logic," and the paper on service ecosystems by Akaka and Vargo (2015). Furthermore, the positive (besides rollercoasting) trends observed since 2012 can be associated with the call for research that Vargo and Lusch made in their paper co-authored with Wieland and Polese, in which they "invite[d] other scholars to contribute to the evolution and development of a better understanding of the collaborative, systemic nature of value creation" (Wieland et al., 2012, p. 21).

Related to this trend, the analysis acknowledged the topic of the context of the value co-creation process. Thus, the dynamics of the value co-creation process were first described as occurring within service systems, or, more specifically, product-service systems (PSS) (e.g. Neely, 2008). Other authors (e.g. Alter, 2010) considered service systems and SDL as partial partners in the exploration of the value co-creation process. A major shift occurred with Akaka et al.'s (2012) development of service ecosystems; the service ecosystem has become a crucial concept in service research. Further conceptualizations of the context of the value co-creation process are developing toward the service ecotone (Simmonds and Gazley, 2018), which is essentially a system of service ecosystems - basically, an extension of the context in which actors perform their roles and tensions and in which interactions move toward value co-creation. Clearly, most of the self-advancing citations (16 out of 20) are placed in SDL and service studies. They are concentrated mainly between 2006 and 2012, with the exception of Vargo and Lusch (2016). It is interesting to observe the evolution of their thinking; in 2006, they "argue[d] that in S-D logic, 'services' is a goods-dominant (G-D) logic term" (p. 282) and then offered revisions of the FPs of the 2004 article (2008a). Wieland et al. (2012) suggested that "S-D logic and service science both point toward a need for a systemic understanding of value and value creation [... to better understand value creation processes" (2012, p. 13). Finally, Vargo and Lusch offered "an updated statement and rationale of the S-D logic foundational premises” (2016, p. 16).

Self-advancement played a crucial role in the theoretical advances of SDL - another main topic recognized in the analysis. Vargo and Lusch continuously refined SDL, first by refining the FPs in Vargo and Lusch (2008a, b) and later reframing them into axioms (Vargo and 
JSTP

31,4

\section{8}

Table 5.

Breakdown of

categories and sub-

categories along time

(in numbers and in

percentages)

\begin{tabular}{|c|c|c|c|c|c|c|c|c|c|c|c|c|c|c|c|c|c|c|c|c|c|c|}
\hline 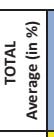 & & & & & & & & & & & $\approx$ ఇ & & $\stackrel{0}{0}$ & & & & & 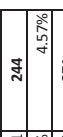 & & 紟 & 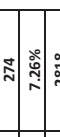 & 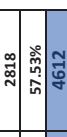 \\
\hline పี & $\nabla \frac{\circ}{4}$ & & & & & 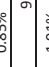 & & & & 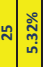 & 이 & רั้ & 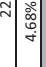 & & શิ & & & $m$ & & هُ: & 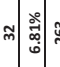 & : \\
\hline ثे & 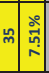 & & & & & 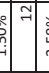 & & 㐌 & 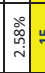 & 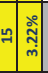 & & & 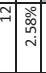 & 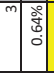 & 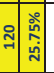 & & 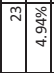 & in & & ๙ั) & 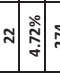 & 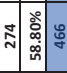 \\
\hline : & ऽ) & & & & & 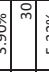 & 今్ & 每 & : & $=$ m) & & & $\left.\begin{array}{c}\pi \\
\hdashline \\
\sigma \\
\sigma\end{array}\right]$ & 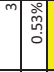 & 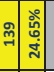 & & . & & & 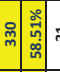 & 无 & จุ \\
\hline 윰 & 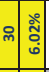 & & & & & |. & L & 势 & : & m & $\circ$ & 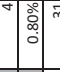 & तี| & & 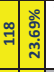 & & & 泾 & & = & • & 怘 \\
\hline 苦 & $=$ = & & & & & 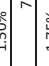 & | & 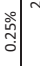 & & 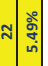 & 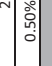 & & 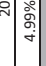 & & 7 F & & & & 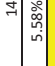 & $\approx$ శ్ & m & هి \\
\hline : & 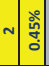 & & & & & s. & & స్ํำ & & & & (1) & $\circ$ & & مْ & & & & & 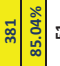 & تص & 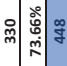 \\
\hline : & 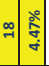 & & & & ఫे & 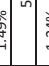 & ક્ّ๋ & & & ล & 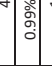 & 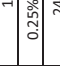 & "ี & & : & & & (2) & & 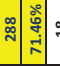 & $=$ & จ̊ \\
\hline 范 & 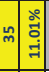 & & & & ఫे & : & : تَّْْ: & 总 & & 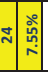 & 年 & 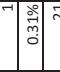 & : & & 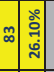 & & 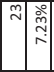 & 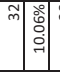 & & 气 & 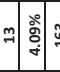 & 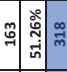 \\
\hline 욤 & $\approx$ & & & & 乌ั & م. & | & | & & $\stackrel{4}{\sim}$ & 产 & 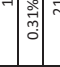 & | & & $\therefore$ : & & 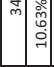 & 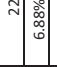 & & $\stackrel{m}{m}$ & 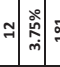 & 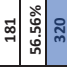 \\
\hline : & m 离 & & & & ذे & : & & & & ^ & 年 & 䜌 & הิ & & 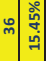 & & 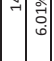 & il & : & đa & $\nabla \mid$ & : \\
\hline : & $m=\frac{8}{\pi}$ & & & & ת & 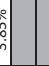 & & & 瓷 & $\infty \frac{\circ}{0}$ & & & $\therefore$ & & 잉 & & & จุ๊ & & चَّ & $=$ ᄋ & $\exists \mid$ \\
\hline ఏे & 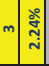 & & & ऐั & c & : & & مُ & & 凹 & 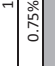 & & 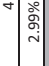 & & 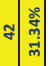 & & & مُ & | & ळ & $m=$ & 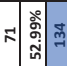 \\
\hline$\stackrel{\text { ¿ }}{\circ}$ & ஸ & & & & $\approx$ & & & 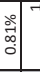 & & $\approx \begin{array}{l}0 \\
\vdots \\
\vdots \\
\vdots\end{array}$ & 产 & $\mid$ & 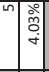 & & ح & & & 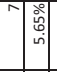 & & ه & - & 品 \\
\hline 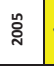 & 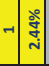 & & & & & f. & & & & $\sim$ 〜 & 裉 & 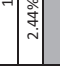 & & & ה & 势 & & 害 & & 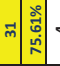 & $>$ ナ & 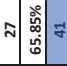 \\
\hline & 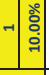 & & & & & & & & & & & & & & n & & 茴 & & & $m \mid \begin{array}{ll}|c| \\
\vdots \\
\vdots \\
\vdots \\
0\end{array}$ & $\sim$ N & $=$ - \\
\hline & 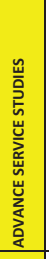 & 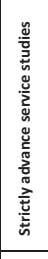 & 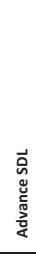 & 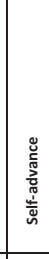 & 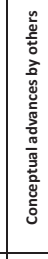 & 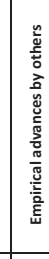 & $\frac{3}{4}$ & 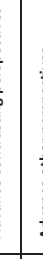 & بُّ & 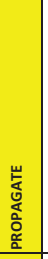 & 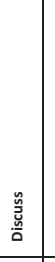 & 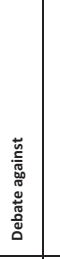 & 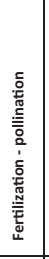 & 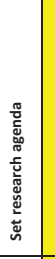 & $\begin{array}{l}\text { zo } \\
\text { 音 } \\
\text { a }\end{array}$ & 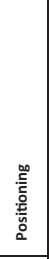 & 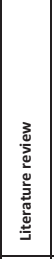 & 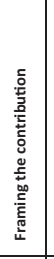 & 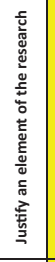 & 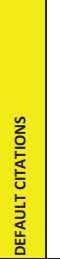 & 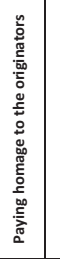 & 童 \\
\hline & & +7 & 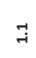 & & & & I & & $\stackrel{m}{\pi}$ & & $\stackrel{i}{i}$ & $\overrightarrow{\mathrm{N}}$ & $N$ & i & & ij & $\vec{m}$ & $\tilde{m}$ & $\stackrel{m}{m}$ & & $\stackrel{8}{+}$ & 7 \\
\hline
\end{tabular}


15 years of

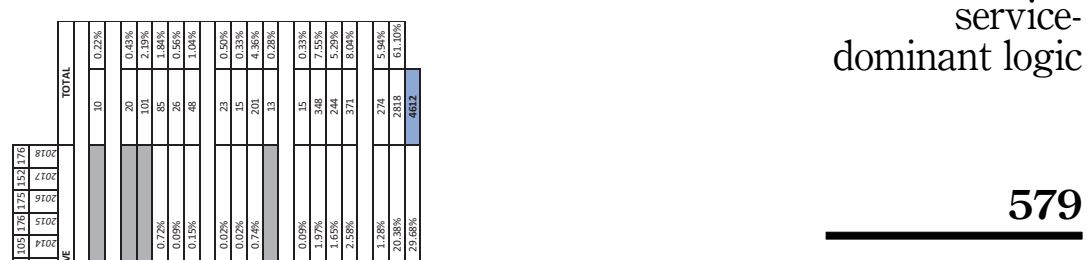

Table 6.

Cross-analysis of categories and methodologies along time 
JSTP

31,4

580

Lusch, 2014) and then service ecosystems (Akaka et al., 2012), leading to the development of the fifth axiom (Vargo and Lusch, 2016). Figure 2 clearly shows how these theoretical advances initiated research within the fields of SDL and service, but also beyond, mirrored in the increased number of citations of the original SDL article. The main question that arises and that is linked to this sub-category and the topic regards the continuation of theoretical advances in SDL. Vectors of diffusion suggested by Vargo and Lusch (2017) may pave the way toward future developments. Based on our results, the implementation of SDL and service ecosystems in international marketing may represent one of the most fruitful developments due to the limited number of contributions investigating the cross-fertilization between the fields (one example is Akaka et al., 2013b).

As expected, the contributions citing V\&L04 to propose conceptual advances fall mainly in the fields of SDL and service studies -78 out of 104 . For instance, Peñaloza and Venkatesh proposed a "re-conceptualization by extrapolating from seminal interpretive and critical work in consumer behavior and market studies" (2006, pp. 300-301). Schembri (2006) adopted a similar approach that incompletely defined the theory conceptualized by Vargo and Lusch and advocated for the development of new directions, focusing on the customer's experience.

Similar results emerge when one looks at "Empirical advances by other authors", even if additional contributions fall into the fields of management and marketing, with attention paid to various actors shaping the value co-creation process. In any event, this sub-category first appeared in 2010, with a limited number of occurrences and an increasing trend (apart from 2011), achieving a considerable peak in 2016. In this sub-category the topic of consumer behavior and new consumer groups emerged, with authors proposing empirical research beginning with the notion of value-in-use and its reflection in the ongoing market changes. For example, Macdonald et al. (2011) investigated the dynamics leading to value-in-use in buying groups, describing value-in-use as pertaining to single users, but depending on the collective dimension. Actor contribution to value co-creation was also highlighted by Kowalkowski et al. (2012) in their depiction of the co-creative practice of forming a value proposition, relying on V\&L04 to refer to both the co-creative paradigm and the meaning of value proposition. Similarly, the role of users and the changes in retailing systems were combined to study value co-creation behavior, depending on customers' interactions with brands (Shamim et al., 2016) and on buying groups (Macdonald et al., 2011), still leaning on value-in-use as proposed in V\&L04. Halliday (2016), starting from the concepts of SDL and referring to the more active behavior of the consumer, investigated the activities of young people to determine which activities were motivated mainly by Web 2.0. Indeed, more recent years have seen the rise of articles dealing with consumer behavior and consumer experience in digital environments (e.g. Molesworth et al., 2016; Koch and Windsperger, 2017; Saunila et al., 2017; Vendrell-Herrero et al., 2018; Weitzl and Einwiller, 2018). Therefore, we can expect scholars to continue investigations within these topics, perhaps focusing on youth consumer behavior online, as millennials - digital natives - represent new consumer groups with specific behavioral patterns.

As concerns V\&L04 citations intended to propose other perspectives, the low number of contributions leads to an almost total heterogeneity of fields in the sub-category "Advance contrasting perspectives." On the other hand, "Advance other perspectives" contains a concentration of results, with 31 out of 48 contributions falling into the service studies field. For example, Malone et al. (2018), starting from SDL premises, proposed advancing other perspectives when examining "how emotions, as one type of customer operant resource, shape the value creation process from a $\mathrm{CD}$ logic perspective by considering both positive and negative emotions in the consumer's experience of tourism” (p. 3). Similarly, Heinonen and Strandvik (2015) contrasted CDL (customer-dominant logic) with SDL and SL (service logic), with a special reference to the role of the involved actors; in detail, they focused their paper on managerial issues aimed at a more relevant role of academic research for managers. In this 
way, they offered a contribution appearing as a direct response to SDL. More recently, Strandvik et al. (2019) emphasized CDL by stating that customer value emerges beyond what providers can observe.

The trends falling under "Advance other perspectives" fluctuate considerably (see Figure 2), with a peak of 12 in 2017, forerun by a peak of 10 in 2016. Similar evidence emerges when one considers "Advance contrasting perspectives," whose highest peak was in 2015, with seven occurrences detected. These trends correspond with the 2014 publication of Lusch and Vargo's book The Service-Dominant Logic of Marketing: Dialog, Debate, and Directions (an updated version of the 2006 book), which probably stimulated debate on the topic, as well as on related topics, as confirmed by the high number of citations.

In conclusion, Category 1 appeared to be one of the most interesting in terms of helping us discuss the implications of SDL evolution and debate service marketing thought. It is important to observe that the number of citations in this category grew considerably from 2013 to 2016 and that this growth was followed by a slight decline in 2017 and 2018. However, the trends throughout the analyzed period have been quite constant, with peaks every fifth year for almost every sub-category. Finally, another result to be mentioned concerns the fields. Indeed, the first three sub-categories (namely, "Self-advance," "Conceptual advances by other authors" and "Empirical advances by other authors") relate mainly to service studies and marketing. The last ones ("Advancing other perspectives" and "Advancing contrastive perspectives”) present a notable heterogeneity of fields.

\section{Category 2 - Propagate}

The category "Propagate" includes contributions that referenced V\&L04 to propose theoretical debates and empirical discussions from different perspectives and with motivations other than advancing service studies, as in Category 1. Moreover, we identified three main research topics, i.e. engagement, delivery systems and logistics, and crowd-based business models, among others, that are useful in summarizing the results of the contributions in this category. Moreover, these topics have the potential to lead to new advances in service research.

The category "Propagate" emerged as the least numerous among the four categories, as it includes 252 contributions - namely, $5.81 \%$ of the dataset (see Table 5). The trend is quite stable, with a peak in 2006 and relevant increases from 2010 to 2012 and 2014 to 2015, and again in 2018. The peak in 2006 stemmed partially from the chapters in the book on SDL, embedding influential contributions to date. Conversely, from 2010 to 2012 , the increase in occurrences stemmed primarily from the combination of SDL with other research fields. Similarly, there was a relevant increase from 2014 to 2016, also because of service innovation (Lusch and Nambisan, 2015) infused into V\&L04. In all years, marketing clearly represented the most common field of science, though even supply chain management (SCM), innovation, and tourism played a relevant role in the frequent citing of V\&L04. The contributions in this category are mainly conceptual $(54 \%)$, while qualitative research outbalances quantitative research almost twice as much. The most recent peak occurred in 2018, with contributions in a variety of research areas, although the most discussed topic was branding. For example, Leckie et al. (2018) linked brand engagement with value co-creation and service innovativeness. Our analysis revealed that engagement, particularly customer engagement, supported the propagation of SDL, as in, for example, Brodie et al. (2011), who conceptualized customer engagement in multiple relationships from an SDL perspective. Customer engagement has continued to develop, as in Hardyman et al. (2015), who investigated the micro level of SDL through patient engagement. The discourse on engagement has slowly been steered toward brand engagement because of the effect of social media, as in Gong (2018), who measured customer brand engagement in online brand communities and emphasized the role of cultural value orientation and brand responsibility
15 years of servicedominant logic 
JSTP 31,4 in the value co-creation process. Therefore, more research on engagement, both customer and brand engagement, is expected, especially in relation to digital engagement and the effect of new technologies on customer behavior, brand management, and value-in-use (see also Breidbach et al., 2014).

Regarding the sub-categories, the first one, "Discuss," is not at all common, with only 23 occurrences from 2004 to 2018. The sole peak was in 2006 and was due to some of the chapters in the 2006 book. In one, Hunt and Madhavaram (2006) discussed SDL through the resourceadvantage theory by analyzing the theoretical foundations that V\&L04 proposed, mainly starting from the operand and operant resources. More recently, Williams (2012) debated scholars' understanding of the FPs. The most common fields in this sub-category are marketing and service studies. As expected, most of the contributions in "Discuss" cite V\&L04 for conceptual reasons (see Table 5).

An even less frequent reason to cite is "Debate against." In 2013, Wikhamn et al. (2013) proposed a criticism when describing Volvo's servitization process. In 2015, Sesselmann (2015) adopted an upside-down perspective when investigating customer integration, neglecting SDL. Also, Hietanen et al. (2018) opposed the idea of extending SDL into a theory of society and claimed that SDL's neoliberalist perspective is unsuitable for social theorizing. However, one of the most severe critiques was that of O'Shaughnessy and O'Shaughnessy (2009), who described SDL as a backward step, activating a back-and-forth debate with Vargo and Lusch. Overall, the criticisms are framed in marketing studies and focus mostly on theoretical incongruences between the extant marketing literature and SDL. Most of the contributions citing V\&L04 in "Debate against" are conceptual.

On the other hand, "Fertilization - pollination" is the sub-category that most affects the overall results of the category "Propagate." From 2007 on, it emerged as the most frequent occurrence among the four sub-categories. Peaks in 2010, 2011, and 2015 were always over $6 \%$ of the entire year's contributions, while the average of the entire period was only $3.66 \%$ (see Table 5). Studies on information technology (IT) and information science (IS), SCM and logistics, innovation, and tourism were mostly affected. For example, Truong et al. (2012) built on the concept of value proposition to question the constraints to reciprocal value propositions in digital markets, while Wang (2015) recalled V\&L04 to describe service experiences through mobile devices, and Augustsson et al. (2015) investigated the role of IT in technological and service transitions. Most of the peaks may be partially explained due to new emerging concepts, such as value-in-context and service innovation, with V\&L04 cited as the embryo of these new concepts, as in Chester Goduscheit and Fallant (2018), who recognized the relevance of V\&L04 in proposing a multidimensional perspective for service. Additionally, Lusch and Vargo, together with Tanniru (2010), constitute a relevant example of initiators of the fertilization process when combining SDL and SCM. Indeed, from that moment on, several papers about SCM and logistics were issued, such as Liu and Deitz (2011), who proposed future research through quantitative analysis. Fertilization and pollination of this field of research with SDL continued even more recently with Randall et al. (2014), who found SDL to be particularly fitting with the logic of performance-based logistics. The authors conducted an empirical investigation that put into practice several SDL concepts in logistics.

Newer contributions have continued on a similar path; for example, Carbone et al. (2017) analyzed the logistics processes in the new paradigm of the sharing economy to understand the novel contribution they may offer to value co-creation. Thus, we expect further advances within this topic, especially when new means of deliveries and logistics are concerned, such as delivery drones, food delivery platforms, and the sharing economy, all potentially fruitful empirical contexts merging SDL and logistics.

The sharing economy is particularly interesting in this aspect, considering the four types of sharing economy platforms (Schor, 2014) and the similarities and differences in value flows 
in particular types of platforms. A similar infusion of SDL can be observed in innovation studies, exemplified by Ordanini et al. (2011) through a focus on crowdfunding and the chapter by Hasu et al. (2015) about resource integration as a path toward innovation.

Other authors also considered crowd-based business models; for example, Egger et al. (2016) determined that crowdsourcing is a way to set new tourism initiatives through the support of ICT and open innovation. The authors developed a framework highlighting the role of peer-to-peer networks in novel tourism initiatives. Similarly, Liu et al. (2018) emphasized the importance of levering users' ideas to achieve open innovation in multiple fields, considering users' ideas to be a new mechanism favoring value co-creation. Thus, our analysis of SDL fertilizing the field of innovation revealed that the topic of crowd-based business models needs further development. Consequently, we encourage further research into such models through an SDL perspective, considering how the contributions we emphasized show the centrality of value co-creation to such business models.

In summary, the sub-category "Fertilization - pollination" hosts an almost equal number of conceptual contributions and empirical studies, while quantitative studies represent less than $17 \%$ of this category (see Table 5).

Finally, few contributions appear in the last sub-category, "Set research agenda," as only 13 papers cited V\&L04 primarily to call for research. This trend shows a significant increase from 2015 to 2017, with almost all the contributions framed in service studies and marketing research. Social media is the main topic inspiring SDL-framed calls for research - e.g. Ostrom et al. (2015), identifying service research priorities, and Hofacker and Belanche (2016), setting social media challenges for marketing practitioners. This sub-category also includes the paper by Vargo and Lusch (2017), anticipating the expected advances of SDL until 2025. As expected, service research is the key field hosting the occurrences of this sub-category, and almost all the contributions are conceptual. Consequently, we must emphasize some of the proposed research in these contributions, especially how social media shape relationships among multiple actors in a perspective based on value co-creation (Hofacker and Belanche, 2016) and issues of sustainability and sustainable development (Vargo and Lusch, 2017).

In summary, the fertilization effect dominates the category "Propagate," with SDL infused into several scientific domains. Indeed, "Fertilization - pollination" is the only sub-category of the category "Propagate" to contain a variety of research fields framing the entries and sources hosting them. It is relevant to highlight that new fields of science advancing through SDL have represented a non-stop process since 2006. Furthermore, the advances were inspired by new conceptualizations, such as service innovation, though V\&L04 maintained a key role in expanding other fields of research, as well as inspiring calls for research.

\section{Category 3 - Position}

The number of citing contributions in the category "Position" oscillated quite a bit (see Figure 2). Indeed, with an average of $22.75 \%$, there are some peaks, as in 2004 , when the total number of citations reached $50 \%$, and 2007 , with $31.34 \%$. On the other hand, declining peaks can be observed in 2013 and 2014, when the total number of citations was below $13 \%$. The findings in this category and its sub-categories highlight the research topics of innovation and ethics.

Plenty of evidence can be observed through the trends: three out of four sub-categories reached their highest peaks in the last three years (see Table 5). Notable peaks also emerged in 2007, 2010 (with a considerable positive trend since 2008), and 2016 (with a positive trend starting from 2014). However, V\&L04 was used mainly as a significant element of the "Literature review," with an average of $10.08 \%$ (see Table 5), and in various fields. In fact, even if related mainly to marketing (Friman et al., 2020), service studies (Vargo and Akaka, 2009), and innovation (Edvardsson et al., 2006; Roberts et al., 2014), a high number of
15 years of servicedominant logic

583 
JSTP 31,4

584

contributions pertaining to consumer behavior (e.g. Kelleher and Peppard, 2011) and SCM (Esper et al., 2010) emerged. For instance, Babin and James (2010), in their conceptual paper on consumer behavior, focused on the creation of value, citing V\&L04 as one of the pillars of the theoretical background. Santala and Parvinen (2007), in describing the concept of customer value, mentioned V\&L04, stating that "value-in-use perspective is purported by the propositions of service dominant logic which combines advances of different schools of marketing thought into a new perspective" (p. 584).

In 2007, a peak is particularly evident when one observes the entire category (see Figure 2), but "Literature review" is the sub-category that mainly contributes to the trends. In this regard, we assume that the first book by Vargo and Lusch (2006) influenced the number of "Literature review" citations, leading to a peak in 2007. Similarly, we deduce that the papers that Vargo and Lusch published in 2008 inspired and increased interest in the topic and that, consequently, the number of citations of the key paper in each category grew considerably. Finally, in 2016, the "Position" category reached its final peak (see Figure 2), mainly because of the "Literature review" sub-category, depicting an increasing trend that started in 2014 and was likely associated with the publication of Lusch and Vargo's (2014) third book, as well as with two additional contributions that they provided, with other service scholars, on the connection between SDL and innovation. Scholars frequently explored this connection. For example, Järvinen and Lehtinen (2004) offered a definition of e-service and noted the innovation and emerging trend of SDL. In their literature review, they considered SDL useful in describing the concept of service and its potential. A similar perspective was adopted by Nilsson and Ballantyne (2014), who revised the conceptualization of servicescape, building on what V\&L04 proposed as service and as operand and operant resources, stating that a servicescape is an operand resource. Moreover, Blazevic and Lievens (2008) offered insights into how to manage innovation in the case of customer involvement and how this involvement affects the value co-creation process. A similar approach was adopted by Desai (2012), with reference to emerging countries, to propose a conceptual framework to investigate value dynamics. More recently, Zaborek and Mazur (2017) recalled the well-established DART model (Prahalad and Ramaswamy, 2004) and combined it with innovation, simultaneously recalling V\&L04 to describe the essential features of service offerings in SDL and to establish the theoretical elements of their research. Finally, Saragih and Tan (2018) reviewed the literature on co-innovation and proposed a conceptual framework to describe the key elements of the debate on innovation, open innovation, and co-innovation. Therefore, more research in this topic is expected.

In terms of sources, most of the analyzed books and chapters cited V\&L04 as a relevant element of the literature review; accordingly, most of the contributions citing V\&L04 are conceptual. This trend is consistent throughout all the sub-categories (see Table 5). With respect to the fields, not many differences emerge when one compares the two other subcategories, "Framing the contribution" and "Justify the element of the research." (The results related to sub-category 3.0, "Positioning," have been considered less relevant due to the very low number.) Indeed, most of the publications citing V\&L04 as a means of framing the contribution or justifying an element of the research deal with the marketing, innovation, ethics, and services fields. In particular, the topic of ethics stands out in this category; for example, Enquist et al. (2006) framed their contribution on corporate social responsibility in SDL and analyzed banks, focusing on the adoption of responsible practices toward their customers. The debate on ethics and responsible behavior, framed or justified with the help of SDL, continued, as in Özçağlar-Toulouse et al. (2009), who studied fair trade and described the contribution of multiple actors to innovation, implementing and expanding the concept of cocreation. More recently, Rousselet et al. (2018) focused on ethics as a part of customer-related and work-related situations that affect value co-creation. Therefore, we expect the research on ethics and responsible behavior, framed or justified with the help of SDL, to continue. One 
possible avenue is the application of sustainable development goals set by the United Nations, scarcely considered in the SDL discourse.

Moreover, in 2014, as well as in 2016, the sub-category "Framing the contribution" reached a very low peak, probably due to the increasing number of contributions on the theme offered by both the same authors and other service scholars. This led to the use of more recent studies to justify the research, while the key paper was used mainly as an assimilated element in the literature review. On the other hand, the number of citations used to frame the contribution reached its highest peaks in 2011 and 2017; this result can be associated with the Journal of Business, Market and Management special issues, as well as the Handbook on Service Science (Maglio et al., 2010), which could have stimulated new proposals to be contextualized. For instance, Sichtmann et al. (2011), in their paper on quality control, applied V\&L04 as the most important theory on service provision. However, this stimulating effect is perhaps fading, given the significant decrease in the number of contributions in this category in 2018.

Finally, particularly interesting are the trends in the last sub-category, namely, "Justify an element of the research"; indeed, the number of contributions in it reached the lowest peak in 2014 and the highest peak in 2015 . However, 2014 represents a very low peak for the three subcategories, while we assume the peak in 2015 can be associated with the publication of the first two papers on the service ecosystem, leading to the proliferation of new - mainly conceptual proposals (see Table 5). In general, most contributions citing V\&L04 as a justification deal with marketing, management, and innovation. For example, Bowden et al. (2015) considered V\&L04 theory to be a relevant element for conceptualizing strong customer-brand relationships; similarly, Tollin and Schmidt (2012) did the same with reference to the role of interactions in framing a new marketing logic, as proposed by V\&L04, while Lewin et al. (2015) and Gruber et al. (2009) referred to V\&L04 to describe the attributes of products, services, or behaviors. Moreover, Muzellec et al. (2015) focused on value propositions in the Internet business model and contrasted V\&L04 with more recent views. Finally, the highest number of contributions citing V\&L04 to justify an element of research appeared in 2018, with 73 out of 371, which was almost double the number from 2017. This result largely depended on papers citing "Servicedominant logic 2025" (Vargo and Lusch, 2017) and simultaneously recalling V\&L04.

In summary, 2011, 2016, 2017 and 2018 appear to be the most interesting years. In 2011, the number of citations for each sub-category is very similar; in 2016, the number of citations for each sub-category is completely different, while, in 2017, "Literature review" and "Framing the contribution" show opposite trends. In 2018, the category boomed, due to the peak in the sub-category "Justify an element of research." These tendencies, as previously stated, can be associated with the publication of new theoretical contributions to the theme, leading authors to cite V\&L04 as a relevant feature of the general debate on the topic and as a way to position the contribution.

\section{Category 4 - Default citations}

This category is composed of two sub-categories of citations, "Paying homage to the originators" and "General citations" (see Table 3). Overall, while there are only two subcategories, most of the citing contributions fall into Category 4, constituting $64.79 \%$ of the dataset. Homages to the originators amount to $7.26 \%$, while general citations dominate, with $57.53 \%$ of the dataset (see Table 5).

The number of contributions in this category is frequently rising, though showing a somewhat steadier pattern than other categories. The most interesting year in the category of "Default citations" is 2013; $85.04 \%$ of the analyzed contributions fall into this category, with a very modest number of advances and debate contributions. A possible explanation for the 2013 peak is that the contributions that were de facto advancing or debating SDL or that used SDL for positioning referred to V\&L04 as the cornerstone article in service research. 
JSTP 31,4
Conversely, the trends from 2014 and further took place due to the 2014 book (Lusch and Vargo, 2014) (with a chapter clarifying what SDL is, is not, and might be), the paper on institutions and axioms (Vargo and Lusch, 2016), and the paper "Service-dominant logic 2025" (Vargo and Lusch, 2017).

Our analysis has shown that this category most suitably mirrors the actual impact and spread of SDL. Not surprisingly, most of the contributions citing V\&L04 in this category fall into the fields of marketing ( $26.84 \%$ of all "Default citations"), service research ( $8.24 \%$ ), brand management $(6.60 \%)$, innovation $(6.27 \%)$, tourism $(4.46 \%)$, and consumer behavior $(3.98 \%)$. However, we also identified studies in fields completely unrelated to business, such as weather studies (Descurieux, 2010), waste management (Cook et al., 2012), and even Shakespearean studies (Rumbold, 2010). These fields, though rare, exemplify SDL's impact beyond marketing. Methodologically, 1,156 contributions in the category were conceptual, 999 used quantitative methods, 925 used qualitative methods, and 12 used mixed methods (see Table 5).

The first sub-category of "Default citations" is "Pay[ing] homage to the originators" of V\&L04. Contributions that generally acknowledge the article's influential role in initiating a new logic for marketing, as well as some of the contributions charting the evolution of marketing thought, fall into this sub-category (e.g. Ranaweera and Sigala, 2015). Our analysis revealed more fluctuations in this sub-category, although its trends follow that of the main category. The most significant peak is in 2013 (see Figure 2), with $11.38 \%$ of all citations that year, while the bottom is in 2015 , with $1.20 \%$, averaging $7.26 \%$ of the annual citations. Most of the contributions in this sub-category are framed in marketing and marketing history, with the latter - rather surprisingly - dominating in 2005. For example, Shaw and Jones (2005) summarized the schools of marketing thought, considering V\&L04 to be a key contribution to marketing just one year after its publication. Similarly, Smith et al. (2012) acknowledged the role of V\&L04 in introducing value proposition and the concept of superior value proposed to customers, while Leroi-Werelds et al. (2017) investigated the most suitable methods for referring to consequences for users and mirrored their focus on the benefits and sacrifices in V\&L04's definition of value-in-use. A more thorough approach to describing the contribution of V\&L04 was proposed by Gummesson and Grönroos (2012) in their article on the Nordic School perspective. Additional evidence was provided by Adams et al. (2014), who recognized the role of V\&L04 in dealing with operand and operant resources, while in a more general vein, Morrar (2014) recognized the role of V\&L04 in "redress[ing] the model of exchange in marketing" (p. 8). More recently, homage to the originators of SDL was acknowledged in the editorial of the Journal of Service Theory and Practice, explaining the new name of the journal as a way to mirror the ongoing changes in marketing studies (Ranaweera and Sigala, 2015). The same journal offered a thought-provoking contribution when launching eight challenges for servitization scholars (Nudurupati et al., 2016).

The homage paid to V\&L04 is not limited to marketing studies. One of the most frequent fields with contributions in this sub-category is management. SDL - and, particularly, V\&L04 - has been recalled in articles and book chapters related to general management, service management, innovation management, and supply chain management. Finally, the contributions in this sub-category are based on a conceptual approach (slightly more than half), while empirical qualitative research is more frequently used in the remaining contributions (74 out of 242 , as opposed to the quantitative approach in 46 out of 242).

The sub-category "A general citation" contributed most to the described trends for the entire category, showing no significant deflections from the general trends as a whole regarding peaks, fields and methods. Most frequently, the authors citing V\&L04 acknowledged and referred to some of the general postulates of SDL, such as the change in the nature of marketing, business becoming more collaborative and involving customers, or the notion of value co-creation. SDL was mentioned both implicitly and explicitly. In the 
latter cases, it was labeled as the prevailing or dominant perspective in modern marketing. However, these contributions rarely delved deeper into SDL or specific issues of value co-creation. Another citation practice in the general sub-category is mentioning the application of SDL as a possible future research avenue, yet without an elaborate explanation, as in the "Setting research agendas" sub-category (2.3). In any case, our analysis revealed that most of the citing authors perceived V\&L04 as probably the most relevant cornerstone in modern marketing studies.

In summary, Category 4, "Default citations," with its two sub-categories, "Paying homage to the originators" and "A general citation," hosts most of the 4,612 citing contributions analyzed. V\&L04 was cited to acknowledge its existence, not least as a starting signal to SDL, and to generally refer and pay homage to the shift in marketing thought. Citations in the fields of marketing, service research, brand management, innovation, tourism, and consumer behavior dominate the category, but the impact of V\&L04 is recognized even beyond business- and administration-related fields of research.

\section{Theoretical implications and future research directions}

The starting point of this study was how and why the approximately 14,000 contributions citing V\&L04 actually used this citation for the purposes of their own research. Drawing on extensive literature from the domain of citation practice studies (e.g. Bornmann and Daniel, 2008; Ding et al., 2014; Liu et al., 2014; Zhao and Strotmann, 2014; Haustein and Larivière, 2015; Khadka and Knoth, 2018), several limitations of previous SDL citation analyses (Pohlmann and Kaartemo, 2017; Wilden et al., 2017; da Silva et al., 2018) were emphasized. To mitigate these limitations, this study analyzed the citation context of the references (Bornmann and Daniel, 2008) to V\&L04 to provide more detailed and direct information about the nature of citation (Ding et al., 2014; Liu et al., 2014) and provide a more thorough understanding of citing motivations via the different purposes of using a specific citation (Liu et al., 2015). In addition, the main research topics related to citation practices have been highlighted, opening future research avenues. In our analysis, we developed a comprehensive framework of citation practices based on the existing frameworks in literature and applied it to 4,162 contributions. Our work complemented the existing citation analyses of V\&L04 (e.g. Pohlmann and Kaartemo, 2017; Wilden et al., 2017; da Silva et al., 2018) by offering a more nuanced analysis and, thus, contributing to SDL, service research and marketing.

The results of the analysis show that most of the advances stemming from V\&L04 are conceptual, with the empirical research exhibiting a certain delay after the main conceptual advances. This is relatively unsurprising, considering the relative novelty of SDL as a perspective. However, despite the relative novelty, SDL is a conceptually well-consolidated field; this kind of consolidation is beneficial because it encourages more relevant theoretical and empirical advances (Honjo, 2000; Schutjens and Wever, 2000) and helps to diffuse the academic findings into business practice efficiently (Schutjens and Wever, 2000). These conceptual developments occurred in leaps (see sub-category "self-advancing") largely corresponding to the periods of SDL evolution identified by Brodie et al. (2019). Thus, the leaps can be explained by the advances of SDL (Vargo and Lusch, 2008a, b, 2016), when V\&L04 was used to self-advance and advance SDL, indirectly causing leaps, rises and peaks in the number of citations. These leaps helped increase the number of citations, but also influenced empirical advances to shift the foci in constant attempts to catch up with the perpetual conceptual advancement. In this sense, although it is natural for a relatively young and still-developing field to constantly advance primarily conceptually, such constant leaps may in fact represent certain constraints for the empirical research. For example, the concept of service ecosystems was introduced, and research in it virtually exploded well before the previous concept of service systems could have been explored to its full potential. This fast
15 years of servicedominant logic 
JSTP 31,4

588 development is illustrated by Skålén et al. (2015), who explored the service systems of Arab Spring, but used an additional note at the end of the article to emphasize that the article actually explored service ecosystems and not service systems.

Our analysis also highlighted several research topics that stood out in their particular categories, as distinct contexts in which the general theory meets practice and where they influence each other; in other words, these topics can be considered midrange theories (Brodie and Peters, 2020) that have the potential to further drive the development of SDL, while contributing to their own respective fields. The next section highlights these contexts based on the categories and the analysis, and develops representative research questions that have the potential to drive the respective topics/fields and contribute to the further development of SDL (see Table 7).

Starting with the first category, "Advance service studies," we noticed the research topic concerning conceptualizations of value. While value-in-use is still a concept firmly remaining from the original V\&L04 article, other conceptualizations and contextualizations of value have been discussed, for example, value-in-context (Chandler and Vargo, 2011), value-inexperience (Jakkola et al., 2015), and value-no-creation (Makkonen and Olkkonen, 2017). Further investigation of the interplay of value-in-use and these associated concepts can propel knowledge on value creation and contribute to theories of value. In this regard, we complement Brodie et al.'s (2019) suggestions to investigate actors' experiences with respect to value, with a set of RQs aimed at further explorations of how context, experience, and social features may influence value creation, as well as RQs concerning the nature of value creation with respect to these conceptualizations. Next, the analysis observed a continued conceptual development of SDL, leading to service ecotones (Simmonds and Gazley, 2018) and service ecology (Ng et al., 2019). Essentially, service ecotones are service ecosystems of service ecosystems. We highlight several possible RQs concerning service ecology (see Table 7) and emphasize that this level of abstraction might bring another level to the micro-, meso-, and macro-levels of SDL, namely, the supra-level, with related supra-institutions as potentially the most interesting research avenue. The concept of supra-level institutions started to emerge recently, for example in Frow et al. (2019) and Windahl et al. (2020). The former article embedded a service ecosystem's micro-, meso- and macro-levels within a larger ecosystem's meta-level practices and institutions, while the latter article explained the long-term relevance and consequences of strategic decisions on the meta-level for the evolution of value-creation systems. As more research focusing on the supra-level is needed (Frow et al., 2019; Windahl et al., 2020), our RQs can help to further crystallize this concept.

International marketing and SDL emerged as another research topic (e.g. Akaka et al., 2013b; Kaartemo et al., 2017), emphasizing the need to investigate the topic empirically. However, more advances in this vein are lacking, so research in this topic is encouraged. Presuming that different domestic markets embed different views on value and value creation, depending on, for example, Hall's (1976) high and low context cultures, in Table 7 we developed a set of RQs similar to some of the RQs proposed by Brodie et al. (2019), especially their question "How do the processes of value co-creation differ in specific cultures?". We also charted some RQs related to the recently emphasized role of employees for value creation (e.g. Wirtz et al., 2018); as new technologies are pervading service provision, intricate multiangle customer-employee-robot interactions make the service ecosystem and value co-creation processes even more complex.

Furthermore, our findings show that V\&L04 was used to advance contrasting and other perspectives within service studies in a relatively limited fashion. These advances mostly considered perspectives such as SL (Grönroos, 2011) and CDL (Heinonen and Strandvik, 2015), but also the alternative interpretation of service systems (Alter, 2011). Several contributions recalled V\&L04 to re-conceptualize marketing studies, especially from the field of consumer behavior. Peñaloza and Venkatesh (2006) and Schembri (2006) started this trend 


\begin{tabular}{ll}
\hline Category & Observed topics and issues \\
\hline $\begin{array}{l}\text { Advance } \\
\text { service } \\
\text { studies }\end{array}$ & Conceptualizations of value \\
& \\
Continued theoretical advances in SD & \\
& \\
& \\
Implementing SDL in international \\
marketing
\end{tabular}
marketing

Novel and forthcoming issues in consumer behavior

The role of employees in value cocreation

Continued advances in contrasting perspectives and other perspectives
Research questions

(1) What are different conceptualizations of value?

(2) How do different conceptualizations of value manifest in service ecosystems? How do they interplay?

(3) In which (institutional) contexts do these manifestations emerge?

(4) How do actors navigate the contexts of these manifestations?

(1) How does service ecology emerge?

(2) What are the relationships between individual service ecosystems in service ecology (an ecosystem of service ecosystems)?

(3) How is value circulating in service ecology?

(4) What are the roles of individual actors in service ecotones?

(5) How do supra-institutions emerge?

(1) What are the perspectives on value in different countries?

(2) How is value circulating between the countries with different perspectives on value?

(3) How do colliding institutions interact and merge into new intranational institutions?

(1) How do millennials as digital natives exchange co-creating value in digital service ecosystems?

(2) How are interactions in such service ecosystems affecting their consumer behavior?

(3) How does the social context contribute to shaping value propositions in such digital service ecosystems?

(1) If employees are understood as actors within organizational actors in service ecosystems, what is their role in value creation?

(2) How is the role of employees in service ecosystems changing due to new technologies (e.g. service robots)?

(3) What institutions are emerging due to employee-customer-robot value cocreation?

(1) How do the views on value creation within CDL, SL and other perspectives inform SDL and enable its further development?

(continued)
15 years of servicedominant logic

589 
JSTP

\begin{tabular}{ll}
\hline Category & Observed topics and issues \\
\hline Propagate & $\begin{array}{l}\text { Customer engagement in service } \\
\text { ecosystems based on the Internet of } \\
\text { Things (IoT) }\end{array}$
\end{tabular}

\section{0}

Highlighting incongruencies between the extant (marketing) literature and SDL

Delivery systems and logistics

Crowd-based business models

Position Innovation

Ethics

Default Citations in this category are used too citations broadly for particular topics or issues to Table 7.

\section{Research questions}

(1) How is value circulating in service ecosystems based on IoT, in terms of actors, objects, time, and space?

(2) How are customer engagement mechanisms changing due to the new paradigms, such as IoT?

(3) What institutional disharmonies are leading to new forms of resource integration in service ecosystems based on IoT?

(1) How can traditional marketing models and tools be adapted to SDL? What new models and tools have to be adapted?

(2) How can critical views on institutional theory inform the institutional turn in SDL?

(1) How is value circulating in service ecosystems comprising different types of sharing economy platforms?

(2) How are resources integrated into these different platforms?

(3) What institutions are guiding value creation in particular platforms?

(1) What is the role of value proposition in crowd-based business models?

(2) How is value circulating in the reframed crowd-based business models?

(3) What are the actors, their roles, and their perceptions of value creation in crowdbased business models?

(1) How is value circulating in service ecosystems promoting open innovation?

(2) What are the particularities of resource integration in such a service ecosystem?

(3) What are the actors, their roles, and their perceptions of value creation in this kind of service ecosystem?

(4) What institutions are emerging in such a service ecosystem? Are there institutional disharmonies arising due to multiple actors' differing interests? How do such disharmonies affect value co-creation?

(1) How does ethics as a service ecosystem institution facilitate value creation?

(2) How does the non-ethical behavior of a particular actor shape the circulation of value in service ecosystems?

and were followed by Baron and Harris (2010), investigating the experience, as well as Loane et al. (2015), moving the debate to the domain of social contexts. Here, we have assumed two developments. First, these contrasting and other perspectives have somewhat detached from SDL and are developing as independent research fields, despite the initial benchmark of SDL. One obvious example is CDL. This is why we expect these perspectives to develop their own 
relevant RQs that propel these fields. Second, we expect and suggest more comprehensive review studies comparing and essentially refining the perspectives vis-à-vis SDL. For example, SDL and SL are frequently used interchangeably (e.g. Riivits-Arkonsuo and Leppiman, 2015), which is why distinctions and overlaps are relevant to emphasize, because they essentially capture different aspects of the service phenomenon (Saarijärvi et al., 2017).

Although not a particular topic per se, we also want to emphasize the crucial role of empirical advances in converting SDL's abstractions to a more applicable, managerial level. We have highlighted several contributions critical in this aspect (Karpen et al., 2012, 2015; Brodie et al., 2013; Jakkola and Alexander, 2014), and in general terms, we recommend further emphasis on empirical advances to strengthen the practical relevance of SDL (see also Brodie and Peters, 2020).

The second category, "Propagate," also spawned several research topics, based on which, we developed sets of particular RQs. The "Propagate" category highlighted several, more specific empirical contexts with quite concrete RQs concerning value circulation in the particular service ecosystems related to these contexts. One exciting topic is customer engagement in service ecosystems based on IoT. Customer engagement has been prominent in SDL (e.g. Brodie and Hollebeek, 2011; Breidbach and Brodie, 2017), and new technologies bring forth a reframed understanding of value circulation and relationships between customers, objects, and the environments where resource integration takes place (Verhoef et al., 2017). In addition, IoT breaks the confinements of time and space (Kawsar et al., 2010), thus adding another dimension to customer engagement in service ecosystems based on IoT. Indeed, the empirical settings, such as IoT, Internet of Everything (IoE), and artificial intelligence (AI), have the impetus that could significantly direct SDL (for the latter, see, e.g. Kaartemo and Helkkula, 2018); similarly, Vargo and Lusch (2017) called for research on the third era of big data, also because of the actor-centric behavior.

Furthermore, our findings show that V\&L04 has been used in a very limited manner to discuss SDL or to debate against SDL. As exhibited by the findings, the number of contributions discussing the postulates of SDL or arguing against SDL was more or less constant - albeit low - during the 15 analyzed years and almost vanished in more recent years. For example, the debate was quite fervid a few years after the publication of V\&L04, with O'Shaughnessy and O'Shaughnessy (2009) representing the peak of the debate. The debate between the two pairs of authors seemed to have contributed to a further crystallization of SDL (see Lusch and Vargo, 2011; O'Shaughnessy and O'Shaughnessy, 2011; Vargo and Lusch, 2011b). The most recent article arguing against SDL - and, in this sense, a quite lonely contribution in the last few years - questioned its fundaments as incrementally neoliberal in a world where neoliberalism continues to prove itself insufficient to cope with current political and economic challenges (Hietanen et al., 2018). In fact, in Vargo and Lusch's book (2006) following the original article, the authors themselves invited and initiated discussions of, and debates against, SDL (e.g. Lehmann, 2006; Levy, 2006; Wilkie and Moore, 2006). In light of these results, we must highlight the fact that the lack of contributions discussing and debating SDL invites more such contributions to invigorate the field and initiate a fruitful academic discussion and dialogue. For example, as service research appears to be experiencing an "institutional turn" (Koskela-Huotari et al., 2020; see also Table 1), more critical views of institutions would presumably help to further refine this phenomenon. Institutional theory has, at least in organization studies, been critiqued for over-reach, myopia, tautology, pseudoprogress, and re-inventing the wheel (Alvesson and Spicer, 2019).

Another topic that our analysis identified within the category "Propagate" has been the fertilization of SDL and its pollination to SCM and logistics (e.g. Lusch et al., 2010). This fertilization has been constant and has recently resulted in merging SDL, logistics, and the sharing economy (Carbone et al., 2017). Studying value circulation in such multicollaborative delivery service ecosystems is an exciting research avenue, even more so
15 years of servicedominant logic 
JSTP 31,4

592

considering different types of sharing economy platforms; Schor (2014) emphasized that they are shaped by both their market orientation (for-profit vs. non-profit) and their market structure (peer-to-peer vs. business-to-peer), resulting in four different types of sharing economy platforms. Explicating actors' understandings of value, how resources are integrated and service exchanged, and what institutions guide these processes within each of these four types are intriguing representative RQs that are plotted in Table 7.

Another potentially interesting field of fertilization and pollination is business models. Despite the great relevance of the value proposition in both SDL and business models, few contributions in our analysis addressed these issues in combination. For example, Storbacka et al. (2012) proposed business model design as an activity addressing value proposition, while Adrodegari and Saccani (2017) mentioned V\&L04 merely to further their idea of service transformation in business models. Similarly, Pedersen et al. (2017) depicted the innovation of the business model with reference to the fashion industry, tying it loosely to SDL. The relevance of research combining business models and SDL had been emphasized previously (e.g. Wieland et al., 2017), and some progress has been made since (e.g. Fehrer et al., 2018; Bocken et al., 2019; Nenonen et al., 2019), though more research on value flows in business models from the SDL perspective is needed. Not least, crowd-based business models are interesting, as seen from the findings, which is why we developed a set of RQs particularly concerning crowd-based business models.

The findings in Category 3 showed that V\&L04 was used as a lever to position a new contribution, i.e. to perform the literature review, frame a contribution, or justify an element of research. In line with these citation practices, the analysis has shown that SDL - and especially V\&L04 - acted as a lens to understand recent phenomena. For example, Saragih and Tah used V\&L04 in the proposition of a conceptual framework linking innovation, open innovation, and co-innovation to highlight "the concept of co-innovation that begins by first explaining the SDL perspective, the notion of value innovation, continued with the five constructs of co-innovation along with its possible outcomes and finally proposes a conceptual framework of co-innovation" (Saragih and Tah, 2018, p. 374). This emphasis is even more profound due to the implementation of means such as 3D printing, living labs, and the spread of new logics as social innovation, together with "reconciling diverging views on innovation" (Vargo and Lusch, 2017, p. 58) using SDL. Thus, we derived a set of RQs focusing on the issues of innovation in these new settings (see Table 7). Similarly, framing a contribution with the help of V\&L04 has led the analysis to consider several research topics, with ethics being the most prominent issue. Ethics has been deemed as inherent to value creation and, indirectly, to SDL (Abela and Murphy, 2008), and it affects the decisions of actors participating in service ecosystems (Bridges, 2018). We derived RQs that pivot around ethics as an institution guiding value creation, with some contributions indicating its fundamental role in service exchange (Ferrell et al., 2013; Guitián, 2015).

The findings of our citation practice study of V\&L04 have evidenced that one significant influence of V\&L04 lies in its default, instant recognition, and more general equalization of the initial SDL article with the concept of value co-creation. Consequently, it is very frequently referred to when user involvement is concerned, as well as to indicate the increased interaction between firms and customers and/or consumers in modern business environments and modern society. Thus, V\&L04 has quickly become acknowledged as a default reference that should not be missed when referring in particular to value co-creation and the other two phenomena. A possible explanation of this is the high perceived value and quality of V\&L04 as a cornerstone article of modern marketing studies, which are, in general, the two features of highly cited articles (Tahamtan and Bornmann, 2018). Another frequent usage refers to V\&L04 in future research directions, to briefly indicate the application of SDL as a possible research avenue - something that most probably led to more fertilizations, 
framings of the contributions, and justifications of some elements of research. In this sense, we recognize the existence of a reinforcing loop of citation practices of V\&L04, whereby SDL was more generally indicated as a future research avenue, leading researchers to apply the logic and refer to V\&L04 differently from a default practice. From the aspect of SDL, the presumed citation loop is interesting from its possible contribution to mid-range theories, something which simultaneously represents an intriguing future research avenue for citation practices studies. In any case, these trends are expected to continue with the further development of SDL. Moreover, the analysis has acknowledged several contributions citing V\&L04 in fields of study far removed from SDL and marketing. Weather studies (Descurieux, 2010) and Shakespearean studies (Rumbold, 2010) are two of the most interesting examples in this direction. The effect on knowledge and the role of creativity in language were the two issues respectively leading to the infusion of SDL in these fields of study. Although it is difficult to recommend future research in such fields, on a more general level, we expect more applications of SDL, as the logic continues to inspire scholars from distant fields of research. We believe that SDL has the potential to advance understanding within and the development of such fields of research, adding this perspective to enrich the existing perspectives in the main field. One example is Matthies et al. (2016), who applied SDL as a lens to advance environmental sustainability in interdisciplinary harmony with natural sciences. This contribution has also been identified as a reference for one of the transdisciplinary vectors of SDL (Vargo and Lusch, 2017).

More generally, in the future, we expect that the number of general citations will remain high and that the significant influence of V\&L04 beyond marketing in general and service studies in particular, instantly associating the original article with value co-creation and user involvement, will continue. Thus, it must be acknowledged that this category bears significance, despite its being labeled "general." This is why we also recommend more citation practice research in this particular category to further dissect the scope of the influence of V\&L04.

Besides future research recommendations based on the results stemming from the analysis of the main categories and the associated sub-categories, we emphasize several future research directions related to citation practices. Our analysis focused only on the original article, V\&L04, and we analyzed the citation practices of that single article. In the introduction to our article, we have acknowledged that the focus on one article - although heavily cited - may appear limiting, but that these kinds of investigations are not uncommon within citation practices (see the examples of Sieweke, 2014 and Liu et al., 2015). Nevertheless, analyzing the citation practices of the later self-advances of Vargo and Lusch (2008a, b, 2016, 2017) and cross-referencing the results of such analyses with our results may create additional information and contribute to both SDL and the field of citation practices.

As well as the outline of the citation practices of V\&L04 and the subsequent identification and discussion of the most relevant contributions of this now-seminal paper and the associated future research directions, our article contributed to citation practice research by developing a novel and comprehensive framework of citation practices. Our approach used citation context analysis (Bornmann and Daniel, 2008). This required devising a classification of the text surrounding the particular citation and reading the citing publications to determine the citation context. This novel approach represents a contribution to studies in citation practices: a comprehensive combinative framework built on previous frameworks delineating citation practices (Garfield, 1965, in Smith, 1981; White and Wang, 1997; Case and Higgins, 2000; Aya et al., 2005; Bornmann and Daniel, 2008; Hernández-Álvarez et al., 2016; Tahamtan and Bornmann, 2018), used to assess the context of citations. This comprehensive combinative framework is presented in Table 1. Thus, we recommend that future research continue using this extensive framework for analyzing citation practices in fields other than service studies.

\section{5 years of service- dominant logic}


JSTP 31,4

594

Our additional contribution to citation practices is the extensive application of our framework. Following Bornmann and Daniel's (2008) advice to read the text surrounding the citation to classify it, we applied the framework to 4,612 contributions. In comparison, our results are more robust because previous analyses reviewed by Bornmann and Daniel (2008) analyzed up to 90 articles. In addition, these contributions are intertwined because the framework of citation practices was partially crystalized iteratively through the analysis.

Our final contribution is methodological. First, the analysis of citation practices is not simply a matter of numbers or single issues, as the understanding of results can be achieved only by combining various variables. We identified and combined categories, fields of research, and years as the main elements affecting the evolution of citations. For instance, the identification of fields of research involved in a debate is crucial to describing the expansion of a logic along time, regardless of the development achieved in its own field of research. We regard the methodological approach that we used as leading to a more complete understanding of the development of a theory through one of its key contributions. We are not denying the relevance of other methodological approaches, but are offering a new way to better clarify how a theory can be advanced and propagated, can favor the positioning of additional contributions, be cited to recognize its relevance and pay homage, or be considered more generally. Second, the cross-analysis of elements describing a citing contribution and their relevance over time is not sufficient if the effect of other variables is not considered (see Figure 2). Indeed, the trends we achieved can be better justified only when one considers other related publications. Indeed, the content proposed in V\&L04 was further advanced via books (e.g. Lusch and Vargo, 2006a), new papers (such as Lusch and Vargo, 2006b; Vargo and Lusch, 2008a; Vargo et al., 2008), and additional concepts, e.g. value-in-context (Chandler and Vargo, 2011), service ecosystem (Akaka et al., 2012), and service innovation (Lusch and Nambisan, 2015). Furthermore, events based on the development of a theory (such as conferences), the existence of contrasting theories, the efforts of the initiating authors, the calls launched by editors, and the intervention of other scholars all affect the citations of the original paper. Thus, a complete understanding of the role that a single seminal article had in favoring new contributions can be achieved only by considering connected advances to justify increasing, decreasing, and roller-coasting trends.

Finally, this research led us to describe the reasons to cite as not mutually excluding, but as converging. Indeed, some contributions presented a primary reason to cite, alongside other parallel citation usages. This is relevant for favoring additional analyses and contrasting previous approaches to citation analysis. In any event, such a result can be achieved only through an analysis performed by humans instead of software and on single contributions rather than on groups of them. This emphasizes the advantage of using an in-depth approach to the analysis of studies as compared to software.

To conclude, the results of our study show that V\&L04, the cornerstone article of SDL, revolutionized service research; inspired and instigated fruitful theoretical discussion and debates in the field of service; was applied to propagate and pollinate a variety of academic fields; and is universally recognized outside the scope of service, marketing, and business studies as a synonym for value co-creation, user involvement and customer interaction. This development will undoubtedly continue in the future, not least with the emergence of digital environments, automated service and human-machine interactions.

\section{ORCID iDs}

Marco Tregua Dhttp://orcid.org/0000-0003-1579-7676

Danilo Brozovic http://orcid.org/0000-0001-9579-3266

Anna D'Auria Dhttp://orcid.org/0000-0002-5012-631X 


\section{References}

Abela, A.V. and Murphy, P.E. (2008), "Marketing with integrity: ethics and the service-dominant logic for marketing", Journal of the Academy of Marketing Science, Vol. 36 No. 1, pp. 39-53.

Adams, F.G., Richey, R.G. Jr, Autry, C.W., Morgan, T.R. and Gabler, C.B. (2014), "Supply chain collaboration, integration, and relational technology: how complex operant resources increase performance outcomes", Journal of Business Logistics, Vol. 35 No. 4, pp. 299-317.

Adrodegari, F. and Saccani, N. (2017), "Business models for the service transformation of industrial firms", The Service Industries Journal, Vol. 37 No. 1, pp. 57-83.

Aitken, R., Ballantyne, D., Osborne, P. and Williams, J. (2006), "Introduction to the special issue on the service-dominant logic of marketing: insights from”, The Otago Forum, Vol. 6 No. 3, pp. $275-280$

Akaka, M.A. and Vargo, S.L. (2015), "Extending the context of service: from encounters to ecosystems", Journal of Services Marketing, Vol. 29 Nos 6/7, pp. 453-462.

Akaka, M.A., Vargo, S.L. and Lusch, R.F. (2012), "An exploration of networks in value cocreation: a service-ecosystems view", in Special Issue-Toward a Better Understanding of the Role of Value in Markets and Marketing, Emerald Group Publishing, Bingley, pp. 13-50.

Akaka, M.A., Schau, H.J. and Vargo, S.L. (2013a), "The co-creation of value-in-cultural-context", Research in Consumer Behavior, Vol. 15 No. 10, pp. 265-284.

Akaka, M.A., Vargo, S.L. and Lusch, R.F. (2013b), "The complexity of context: a service ecosystems approach for international marketing", Journal of International Marketing, Vol. 21 No. 4, pp. 1-20.

Akaka, M.A., Vargo, S.L. and Schau, H.J. (2015), "The context of experience", Journal of Service Management, Vol. 26 No. 2, pp. 206-223.

Alter, S. (2010), "Service systems and service-dominant logic: partners or distant cousins?", Journal of Relationship Marketing, Vol. 9 No. 2, pp. 98-115.

Alter, S. (2011), "Making a science of service systems practical: seeking usefulness and understandability while avoiding unnecessary assumptions and restrictions", in The Science of Service Systems, Springer, Boston, MA, pp. 61-72.

Alvesson, M. and Spicer, A. (2019), "Neo-institutional theory and organization studies: a mid-life crisis? ", Organization Studies, Vol. 40 No. 2, pp. 199-218.

Arnould, E.J., Price, L.L. and Malshe, A. (2006), "Toward a cultural resource-based theory of a customer", in Lusch, R.F. and Vargo, S.L. (Eds), The New Dominant Logic in Marketing, M. E. Sharpe, Armonk, NY, pp. 91-104.

Arslanagic-Kalajdzic, M. and Zabkar, V. (2015), "The external effect of marketing accountability in business relationships: exploring the role of customer perceived value", Industrial Marketing Management, Vol. 46, pp. 83-97.

Augustsson, N.P., Holmstrouml, J. and Nilsson, A. (2015), "From technological transitions to service transitions: a study of attenuation effects in IT service provisioning", Journal of Information Technology Services, Vol. 14, pp. 337-354.

Aya, S., Lagoze, C. and Joachims, T. (2005), "Citation classification and its applications”, in Knowledge Management: Nurturing Culture, Innovation, and Technology, pp. 287-298.

Babin, B.J. and James, K.W. (2010), "A brief retrospective and introspective on value”, European Business Review, Vol. 22 No. 5, pp. 471-478.

Barber, C.S. and Tietje, B.C. (2008), "A research agenda for value stream mapping the sales process", Journal of Personal Selling and Sales Management, Vol. 28 No. 2, pp. 155-165.

Barile, S. and Polese, F. (2010), "Linking the viable system and many-to-many network approaches to service-dominant logic and service science", International Journal of Quality and Service Sciences, Vol. 2 No. 1, pp. 23-42.

15 years of servicedominant logic 
JSTP 31,4

Barile, S., Lusch, R., Reynoso, J., Saviano, M. and Spohrer, J. (2016), "Systems, networks, and ecosystems in service research", Journal of Service Management, Vol. 27 No. 4, pp. 652-674.

Baron, S. and Harris, K. (2010), "Toward an understanding of consumer perspectives on experiences", Journal of Services Marketing, Vol. 24 No. 7, pp. 518-531.

Blazevic, V. and Lievens, A. (2008), "Managing innovation through customer coproduced knowledge in electronic services: an exploratory study", Journal of the Academy of Marketing Science, Vol. 36 No. 1, pp. 138-151.

Bocken, N., Boons, F. and Baldassarre, B. (2019), "Sustainable business model experimentation by understanding ecologies of business models", Journal of Cleaner Production, Vol. 208, pp. 1498-1512.

Bornmann, L. and Daniel, H.D. (2008), "What do citation counts measure? A review of studies on citing behavior", Journal of Documentation, Vol. 64 No. 1, pp. 45-80.

Bowden, J.L., Gabbott, M. and Naumann, K. (2015), "Service relationships and the customer disengagement-engagement conundrum”, Journal of Marketing Management, Vol. 31 Nos 7-8, pp. 774-806.

Breidbach, C.F. and Brodie, R.J. (2017), "Engagement platforms in the sharing economy", Journal of Service Theory and Practice, Vol. 27 No. 4, pp. 761-777.

Breidbach, C.F., Brodie, R. and Hollebeek, L. (2014), "Beyond virtuality: from engagement platforms to engagement ecosystems”, Managing Service Quality, Vol. 24 No. 6, pp. 592-611.

Bridges, E. (2018), "Executive ethical decisions initiating organizational culture and values", Journal of Service Theory and Practice, Vol. 28 No. 5, pp. 576-608.

Brodie, R.J. and Hollebeek, L.D. (2011), "Advancing and consolidating knowledge about customer engagement”, Journal of Service Research, Vol. 14 No. 3, pp. 283-284.

Brodie, R.J. and Peters, L.D. (2020), "New directions for service research: refreshing the process of theorizing to increase contribution”, Journal of Services Marketing, Vol. 34 No. 3, pp. 415-428.

Brodie, R.J., Hollebeek, L.D., Jurić, B. and Ilić, A. (2011), "Customer engagement: conceptual domain, fundamental propositions, and implications for research", Journal of Service Research, Vol. 14 No. 3, pp. 252-271.

Brodie, R.J., Ilic, A., Juric, B. and Hollebeek, L. (2013), "Consumer engagement in a virtual brand community: an exploratory analysis", Journal of Business Research, Vol. 66 No. 1, pp. 105-114.

Brodie, R.J., Löbler, H. and Fehrer, J.A. (2019), "Evolution of service-dominant logic: towards a paradigm and metatheory of the market and value cocreation?", Industrial Marketing Management, Vol. 79, pp. 3-12.

Carbone, V., Rouquet, A. and Roussat, C. (2017), "The rise of crowd logistics: a new way to co-create logistics value", Journal of Business Logistics, Vol. 38 No. 4, pp. 238-252.

Case, D.O. and Higgins, G.M. (2000), "How can we investigate citation behavior? A study of reasons for citing literature in communication", Journal of the American Society for Information Science, Vol. 51 No. 7, pp. 635-645.

Chandler, J.D. and Vargo, S.L. (2011), "Contextualization and value-in-context: how context frames exchange”, Marketing Theory, Vol. 11 No. 1, pp. 35-49.

Chester Goduscheit, R. and Faullant, R. (2018), "Paths toward radical service innovation in manufacturing companies - a service-dominant logic perspective", Journal of Product Innovation Management, Vol. 35 No. 5, pp. 701-719.

Cook, M., Gottberg, A., Angus, A. and Longhurst, P. (2012), "Receptivity to the production of product service systems in the UK construction and manufacturing sectors: a comparative analysis", Journal of Cleaner Production, Vol. 32, pp. 61-70.

da Silva, S.V., Nélson, A. and de Carvalho, J.C. (2018), "The first decade of service dominant logic research-a bibliometric analysis", International Journal of Business Excellence, Vol. 14 No. 4, pp. 523-544. 
Day, G.S. (2004), "Achieving advantage with a new dominant logic (Invited commentaries on "Evolving to a new dominant logic for marketing")", Journal of Marketing, Vol. 68 No. 19, pp. 18-27.

Desai, D.A. (2012), "Engaging customers in the emerging countries: is that different?", International Journal of Strategic Change Management, Vol. 4 Nos 3-4, pp. 266-280.

Descurieux, J. (2010), "Post Hoc evaluation of hazardous weather: snowstorms in the Montréal, Québec, area in March 2008”, Weather, Climate, and Society, Vol. 2 No. 1, pp. 36-43.

Ding, Y., Zhang, G., Chambers, T., Song, M., Wang, X. and Zhai, C. (2014), "Content-based citation analysis: the next generation of citation analysis", Journal of the Association for Information Science and Technology, Vol. 65 No. 9, pp. 1820-1833.

Dong, B. (2015), "How a customer participates matters: "I am producing” versus "I am designing"”, Journal of Services Marketing, Vol. 29 Nos 6/7, pp. 498-510.

Doslu, M. and Bingol, H.O. (2016), "Context sensitive article ranking with citation context analysis", Scientometrics, Vol. 108 No. 2, pp. 653-671.

Dresch, A., Lacerda, D.P. and Antunes, J.A.V. (2015), “Systematic literature review”, in Design Science Research, Springer, Cham, pp. 129-158.

Edvardsson, B., Enquist, B. and Hay, M. (2006), "Values-based service brands: narratives from IKEA", Managing Service Quality: An International Journal, Vol. 16 No. 3, pp. 230-246.

Edvardsson, B., Enquist, B. and Johnston, R. (2010), "Design dimensions of experience rooms for service test drives", Managing Service Quality: An International Journal, Vol. 20 No. 4, pp. 312-327.

Edvardsson, B., Tronvoll, B. and Gruber, T. (2011), "Expanding understanding of service exchange and value co-creation: a social construction approach", Journal of the Academy of Marketing Science, Vol. 39 No. 2, pp. 327-339.

Egger, R., Gula, I. and Walcher, D. (2016), "Towards a holistic framework of open tourism”, in Open Tourism, Springer, Berlin and Heidelberg, pp. 3-16.

Enquist, B., Johnson, M. and Skålén, P. (2006), "Adoption of corporate social responsibilityincorporating a stakeholder perspective", Qualitative Research in Accounting and Management, Vol. 3 No. 3, pp. 188-207.

Esper, T.L., Ellinger, A.E., Stank, T.P., Flint, D.J. and Moon, M. (2010), "Demand and supply integration: a conceptual framework of value creation through knowledge management", Journal of the Academy of Marketing Science, Vol. 38 No. 1, pp. 5-18.

Fehrer, J.A., Woratschek, H. and Brodie, R.J. (2018), “A systemic logic for platform business models", Journal of Service Management, Vol. 29 No. 4, pp. 546-568.

Ferrell, O.C., Crittenden, V.L., Ferrell, L. and Crittenden, W.F. (2013), "Theoretical development in ethical marketing decision making", AMS Review, Vol. 3 No. 2, pp. 51-60.

FMM - Forum on Markets and Marketing (2018), "6th Forum on markets and marketing", available at: https://www.eller.arizona.edu/fmm2018 (accessed 17 January 2019).

Friman, M., Rosenbaum, M.S. and Otterbring, T. (2020), "The relationship between exchanged resources and loyalty intentions”, The Service Industries Journal, Vol. 40 Nos 11-12, pp. 846-865.

Frow, P., McColl-Kennedy, J.R., Payne, A. and Govind, R. (2019), "Service ecosystem well-being: conceptualization and implications for theory and practice", European Journal of Marketing, Vol. 53 No. 12, pp. 2657-2691.

Garfield, E. (1965), "Can citation indexing be automated?", in Stevens, M.E., Giuliano, V.E. and Heilprin, L.B. (Eds), Statistical Association Methods for Mechanized Documentation (NBS Misc. Pub. 269), National Bureau of Standards, 1965, Washington, pp. 83-106, 1965. As cited in: Smith, L.C. (1981). Citation analysis. Library Trends, 1981.

15 years of servicedominant logic 
JSTP 31,4
Ghatak, R.R. (2020), "Barriers analysis for customer resource contribution in value co-creation for service industry using interpretive structural modeling", Journal of Modelling in Management, Vol. 15 No. 3, pp. 1137-1166.

Gong, T. (2018), "Customer brand engagement behavior in online brand communities", Journal of Services Marketing, Vol. 32 No. 3, pp. 286-299.

Grönroos, C. (2006), “Adopting a service logic for marketing”, Marketing Theory, Vol. 6 No. 3, pp. 317-333.

Grönroos, C. (2008), "Service logic revisited: who creates value? And who co-creates?”, European Business Review, Vol. 20 No. 4, pp. 298-314.

Grönroos, C. (2011), "Value co-creation in service logic: a critical analysis", Marketing Theory, Vol. 11 No. 3, pp. 279-301.

Grönroos, C. and Gummerus, J. (2014), "The service revolution and its marketing implications: service logic vs service-dominant logic”, Managing Service Quality: An International Journal, Vol. 24 No. 3, pp. 206-229.

Gruber, T., Szmigin, I. and Voss, R. (2009), "Handling customer complaints effectively: a comparison of the value maps of female and male complainants", Managing Service Quality: An International Journal, Vol. 19 No. 6, pp. 636-656.

Guitián, G. (2015), "Service as a bridge between ethical principles and business practice: a Catholic social teaching perspective", Journal of Business Ethics, Vol. 128 No. 1, pp. 59-72.

Gummesson, E. and Grönroos, C. (2012), "The emergence of the new service marketing: Nordic School perspectives", Journal of Service Management, Vol. 23 No. 4, pp. 479-497.

Hall, E.T. (1976), Beyond Culture, Anchor Books, Garden City, New York.

Halliday, S.V. (2016), "User-generated content about brands: understanding its creators and consumers", Journal of Business Research, Vol. 69 No. 1, pp. 137-144.

Hardyman, W., Daunt, K.L. and Kitchener, M. (2015), "Value co-creation through patient engagement in health care: a micro-level approach and research agenda", Public Management Review, Vol. 17 No. 1, pp. 90-107.

Hasu, M., Toivonen, M., Tuominen, T. and Saari, E. (2015), "Employees and users as resource integrators in service innovation: a learning framework", in The Handbook of Service Innovation, Springer, London, pp. 169-192.

Haustein, S. and Larivière, V. (2015), "The use of bibliometrics for assessing research: possibilities, limitations and adverse effects", in Incentives and Performance, Springer, Cham, pp. 121-139.

Heinonen, K. and Strandvik, T. (2015), "Customer-dominant logic: foundations and implications", Journal of Services Marketing, Vol. 29 Nos 6/7, pp. 472-484.

Herlach, G. (1978), "Can retrieval of information from citation indexes be simplified? Multiple mention of a reference as a characteristic of the link between cited and citing article", Journal of the American Society for Information Science, Vol. 29 No. 6, pp. 308-310.

Hernández-Álvarez, M., Gómez, J.M. and Martínez-Barco, P. (2016), “Annotated corpus for citation context analysis", Latin American Journal of Computing, Vol. 3 No. 1, pp. 35-42.

Hietanen, J., Andéhn, M. and Bradshaw, A. (2018), "Against the implicit politics of service-dominant logic", Marketing Theory, Vol. 18 No. 1, pp. 101-119.

Hofacker, C.F. and Belanche, D. (2016), "Eight social media challenges for marketing managers", Spanish Journal of Marketing-ESIC, Vol. 20 No. 2, pp. 73-80.

Hollebeek, L.D., Srivastava, R.K. and Chen, T. (2019), "SD logic-informed customer engagement: integrative framework, revised fundamental propositions, and application to CRM", Journal of the Academy of Marketing Science, Vol. 47 No. 1, pp. 161-185.

Holmqvist, J. and Grönroos, C. (2012), "How does language matter for services? Challenges and propositions for service research", Journal of Service Research, Vol. 15 No. 4, pp. 430-442. 
Honjo, Y. (2000), "Business failure of new firms: an empirical analysis using a multiplicative hazards model”, International Journal of Industrial Organization, Vol. 18, pp. 557-574.

Hunt, S.D. and Madhavaram, S. (2006), "The service-dominant logic of marketing. Theoretical foundation, pedagogy and resource- advantage theory", in Lusch, R.F. and Vargo, S.L. (Eds), The Service-Dominant Logic of Marketing: Dialog, Debate and Directions, M.E. Sharpe, Armonk, NY.

Järvinen, R. and Lehtinen, U. (2004), "Services, e-services and e-service innovations combination of theoretical and practical knowledge", in Hannula, M., Järvelin, A.-M. and Seppä, M. (Eds), Frontiers of eBusiness Research, Tampere University of Technology and University of Tampere, Tampere, pp. 78-89.

Jaakkola, E. and Alexander, M. (2014), "The role of customer engagement behavior in value co-creation: a service system perspective", Journal of Service Research, Vol. 17 No. 3, pp. 247-261.

Jaakkola, E., Helkkula, A. and Aarikka-Stenroos, L. (2015), "Service experience co-creation: conceptualization, implications, and future research directions", Journal of Service Management, Vol. 26 No. 2, pp. 182-205.

Jang, K.K., Bae, J. and Kim, K.H. (2020), "Servitization experience measurement and the effect of servitization experience on brand resonance and customer retention", Journal of Business Research, (advance online publication).

Jayashankar, P., Nilakanta, S., Johnston, W.J., Gill, P. and Burres, R. (2018), "IoT adoption in agriculture: the role of trust, perceived value and risk", Journal of Business and Industrial Marketing, Vol. 33 No. 6, pp. 804-821.

Kaartemo, V. and Helkkula, A. (2018), "A systematic review of artificial intelligence and robots in value co-creation: current status and future research avenues", Journal of Creating Value, Vol. 4 No. 2, pp. 211-228.

Kaartemo, V., Akaka, M.A. and Vargo, S.L. (2017), "A service-ecosystem perspective on value creation: implications for international business", in Value Creation in International Business, Palgrave Macmillan, Cham, pp. 131-149.

Kahneman, D. and Tversky, A. (1979), "Prospect theory: an analysis of decision under risk", Econometrica, Vol. 47 No. 2, pp. 263-291.

Karpen, I.O., Bove, L.L. and Lukas, B.A. (2012), "Linking service-dominant logic and strategic business practice: a conceptual model of a service-dominant orientation”, Journal of Service Research, Vol. 15 No. 1, pp. 21-38.

Karpen, I.O., Bove, L.L., Lukas, B.A. and Zyphur, M.J. (2015), "Service-dominant orientation: measurement and impact on performance outcomes", Journal of Retailing, Vol. 91 No. 1, pp. 89-108.

Kawsar, F., Kortuem, G. and Altakrouri, B. (2010), "Supporting interaction with the internet of things across objects, time and space”, in 2010 Internet of Things (IOT), IEEE, Tokyo, pp. 1-8.

Kelleher, C. and Peppard, J. (2011), "Consumer experience of value creation-a phenomenological perspective", in Bradshaw, A., Hackley, C. and Maclaran, P. (Eds), E - European Advances in Consumer Research, Association for Consumer Research, Duluth, MN, Vol. 9, pp. 325-332.

Khadka, A. and Knoth, P. (2018), "Using citation-context to reduce topic drifting on pure citationbased recommendation", in Proceedings of the 12th ACM Conference on Recommender Systems, pp. 362-366.

Koch, T. and Windsperger, J. (2017), "Seeing through the network: competitive advantage in the digital economy", Journal of Organization Design, Vol. 6 No. 1, p. 6.

Koskela-Huotari, K. and Vargo, S.L. (2016), "Institutions as resource context", Journal of Service Theory and Practice, Vol. 26 No. 2, pp. 163-178.

Koskela-Huotari, K., Vink, J. and Edvardsson, B. (2020), "The institutional turn in service research: taking stock and moving ahead", Journal of Services Marketing, Vol. 34 No. 3, pp. 373-387.
15 years of servicedominant logic 
JSTP 31,4
Kowalkowski, C., Persson Ridell, O., Röndell, J.G. and Sörhammar, D. (2012), “The co-creative practice of forming a value proposition”, Journal of Marketing Management, Vol. 28 Nos 13-14, pp. $1553-1570$.

Leckie, C., Nyadzayo, M.W. and Johnson, L.W. (2018), "Promoting brand engagement behaviors and loyalty through perceived service value and innovativeness", Journal of Services Marketing, Vol. 32 No. 1, pp. 70-82.

Lee, W., Lin, T.M., Lee, W. and Lee, J.R. (2010), "Relational and transactional factors as hybrid criteria for buyer project selection (BPS): an exploratory study from industrial suppliers' perspective", Industrial Marketing Management, Vol. 39 No. 4, pp. 605-615.

Lehmann, D.R. (2006), "More dominant logics for marketing”, in Lusch, R.F. and Vargo, S.L. (Eds), The Service-Dominant Logic for Marketing: Dialog, Debate, and Directions, New York and London, pp. 296-301.

Leroi-Werelds, S., Streukens, S., Van Vaerenbergh, Y. and Grönroos, C. (2017), "Does communicating the customer's resource integrating role improve or diminish value proposition effectiveness?", Journal of Service Management, Vol. 28 No. 4, pp. 618-693.

Levy, S.J. (2006), "How new, how dominant?", in Lusch, R.F. and Vargo, S.L. (Eds), The ServiceDominant Logic for Marketing: Dialog, Debate, and Directions, Routledge, New York and London, pp. 75-82.

Lewin, J., Rajamma, R.K. and Paswan, A.K. (2015), "Customer loyalty in entertainment venues: the reality TV genre”, Journal of Business Research, Vol. 68 No. 3, pp. 616-622.

Light, R.J. and Pillemer, D.B. (1984), Summing up: The Science of Reviewing Research, Harvard University Press, Cambridge.

Liu, G. and Deitz, G.D. (2011), "Linking supply chain management with mass customization capability", International Journal of Physical Distribution and Logistics Management, Vol. 41 No. 7, pp. 668-683.

Liu, A.M.M., Fellows, R. and Chan, I.Y.S. (2014), "Fostering value co-creation in construction: a case study of an airport project in India”, International Journal of Architecture, Engineering and Construction, Vol. 3 No. 2, pp. 120-130.

Liu, S., Ding, K., Wang, B., Tang, D. and Qu, Z. (2015), The Research of Paper Influence Based on Citation Context-A Case Study of the Nobel Prize Winner's Paper, In ISSI.

Liu, Q., Zhao, X. and Sun, B. (2018), "Value co-creation mechanisms of enterprises and users under crowdsource-based open innovation”, International Journal of Crowd Science, Vol. 2 No. 1, pp. 2-17.

Liu, J., Tong, T.W. and Sinfield, J.V. (2020), "Toward a resilient complex adaptive system view of business models", Long Range Planning, p. 102030.

Loane, S., Webster, C.M. and D'Alessandro, S. (2015), "Identifying consumer value co-created through social support within online health communities", Journal of Macromarketing, Vol. 35 No. 3, pp. 353-367.

Lusch, R.F. and Nambisan, S. (2015), "Service innovation: a service-dominant logic perspective", MIS Quarterly, Vol. 39 No. 1, pp. 155-176.

Lusch, R.F. and Vargo, S.L. (Eds) (2006a), "Service-dominant logic", in The Service-Dominant Logic of Marketing: Dialog, Debate, and Directions, M.E. Sharpe, Armonk, NY.

Lusch, R.F. and Vargo, S.L. (2006b), "Service-dominant logic: reactions, reflections and refinements", Marketing Theory, Vol. 6 No. 3, pp. 281-288.

Lusch, R.F. and Vargo, S.L. (2011), "Service-dominant logic: a necessary step”, European Journal of Marketing, Vol. 45 Nos 7/8, pp. 1298-1309.

Lusch, R.F. and Vargo, S.L. (2014), Service-Dominant Logic: Premises, Perspectives, Possibilites, Cambridge University Press, Cambridge. 
Lusch, R.F., Vargo, S.L. and Tanniru, M. (2010), "Service, value networks and learning", Journal of the Academy of Marketing Science, Vol. 38 No. 1, pp. 19-31.

Macdonald, E.K., Wilson, H., Martinez, V. and Toossi, A. (2011), "Assessing value-in-use: a conceptual framework and exploratory study", Industrial Marketing Management, Vol. 40 No. 5, pp. 671-682.

Maglio, P.P., Kieliszewski, C.A. and Spohrer, J.C. (2010), Handbook of Service Science. Service Science: Research and Innovations in the Service Economy, Springer, Boston, MA.

Makkonen, H. and Olkkonen, R. (2017), "Interactive value formation in interorganizational relationships: dynamic interchange between value co-creation, no-creation, and co-destruction”, Marketing Theory, Vol. 17 No. 4, pp. 517-535.

Malone, S., McKechnie, S. and Tynan, C. (2018), "Tourists' emotions as a resource for customer value creation, cocreation, and destruction: a customer-grounded understanding”, Journal of Travel Research, Vol. 57 No. 7, pp. 843-855.

Mars, M.M., Bronstein, J.L. and Lusch, R.F. (2012), "The value of a metaphor: organizations and ecosystems", Organizational Dynamics, Vol. 41 No. 4, pp. 271-280.

Matthies, B.D., D’Amato, D., Berghäll, S., Ekholm, T., Hoen, H.F., Holopainen, J., Korhonen, J.E., Lähtinen, K., Mattila, O., Toppinen, A. and Valsta, L. (2016), "An ecosystem service-dominant logic?-integrating the ecosystem service approach and the service-dominant logic", Journal of Cleaner Production, Vol. 124, pp. 51-64.

McCain, K. and Turner, K. (1989), "Citation context analysis and aging patterns of journal articles in molecular genetics", Scientometrics, Vol. 17 Nos 1-2, pp. 127-163.

Mele, C. (2007), "The synergic relationship between TQM and marketing in creating customer value", Managing Service Quality: An International Journal, Vol. 17 No. 3, pp. 240-258.

Molesworth, M., Watkins, R. and Denegri-Knott, J. (2016), "Possession work on hosted digital consumption objects as consumer ensnarement", Journal of the Association for Consumer Research, Vol. 1 No. 2, pp. 246-261.

Morrar, R. (2014), "Innovation in services: a literature review", Technology Innovation Management Review, Vol. 4 No. 4, pp. 6-14.

Muzellec, L., Ronteau, S. and Lambkin, M. (2015), "Two-sided Internet platforms: a business model lifecycle perspective”, Industrial Marketing Management, Vol. 45, pp. 139-150.

Narin, F. (1976), Evaluative Bibliometrics: The Use of Publication and Citation Analysis in the Evaluation of Scientific Activity, Computer Horizons, Cherry Hill, NJ, pp. 206-219.

Neely, A. (2008), "Exploring the financial consequences of the servitization of manufacturing", Operations management research, Vol. 1 No. 2, pp. 103-118.

Neghina, C., Caniëls, M.C., Bloemer, J.M. and van Birgelen, M.J. (2015), "Value cocreation in service interactions: dimensions and antecedents", Marketing Theory, Vol. 15 No. 2, pp. 221-242.

Nenonen, S. and Storbacka, K. (2010), "Business model design: conceptualizing networked value co-creation”, International Journal of Quality and Service Sciences, Vol. 2 No. 1, pp. 43-59.

Nenonen, S., Storbacka, K. and Windahl, C. (2019), "Capabilities for market-shaping: triggering and facilitating increased value creation", Journal of the Academy of Marketing Science, Vol. 47 No. 4, pp. 617-639.

Ng, I., Maglio, P., Spohrer, J. and Wakenshaw, S. (2019), "The study of service: from systems to ecosystems to ecology", in Vargo, S.L. and Lusch, R.F. (Eds), The SAGE Handbook of ServiceDominant Logic, SAGE, London and Thousand Oaks, CA, pp. 230-240.

Nilsson, E. and Ballantyne, D. (2014), "Reexamining the place of servicescape in marketing: a servicedominant logic perspective", Journal of Services Marketing, Vol. 28 No. 5, pp. 374-379.

Nudurupati, S.S., Lascelles, D., Wright, G. and Yip, N. (2016), "Eight challenges of servitisation for the configuration, measurement and management of organisations", Journal of Service Theory and Practice, Vol. 26 No. 6, pp. 745-763.
15 years of servicedominant logic 
JSTP 31,4

O'Shaughnessy, J. and O'Shaughnessy, N. (2009), "The service-dominant perspective: a backward step?”, European Journal of Marketing, Vol. 43 Nos 5/6, pp. 784-793.

O'Shaughnessy, J. and O'Shaughnessy, N.J. (2011), "Service-dominant logic: a rejoinder to Lusch and Vargo's reply”, European Journal of Marketing, Vol. 45 Nos 7/8, pp. 1310-1318.

Ordanini, A., Miceli, L., Pizzetti, M. and Parasuraman, A. (2011), "Crowd-funding: transforming customers into investors through innovative service platforms", Journal of Service Management, Vol. 22 No. 4, pp. 443-470.

Ostrom, A.L., Parasuraman, A., Bowen, D.E., Patricio, L. and Voss, C.A. (2015), "Service research priorities in a rapidly changing context", Journal of Service Research, Vol. 18 No. 2, pp. 127-159.

Özçağlar-Toulouse, N., Béji-Bécheur, A. and Murphy, P.E. (2009), "Fair trade in France: from individual innovators to contemporary networks”, Journal of Business Ethics, Vol. 90 No. 4, pp. 589-606.

Payne, A. (2006), "Towards an integrated approach to co-creation", Paper Presented at Workshop on New Direction in Relationship Marketing, EIASM Brussels, 7-8 November.

Payne, A.F., Storbacka, K. and Frow, P. (2008), "Managing the co-creation of value", Journal of the Academy of Marketing Science, Vol. 36 No. 1, pp. 83-96.

Payne, A., Storbacka, K., Frow, P. and Knox, S. (2009), “Co-creating brands: diagnosing and designing the relationship experience", Journal of Business Research, Vol. 62 No. 3, pp. 379-389.

Payne, A., Frow, P., Steinhoff, L. and Eggert, A. (2020), "Toward a comprehensive framework of value proposition development: from strategy to implementation”, Industrial Marketing Management, Vol. 87, pp. 244-255.

Pedersen, T., Devinney, T.M., Tihanyi, L. and Camuffo, A. (2017), Breaking up the Global Value Chain, Emerald Publishing, Bingley.

Peñaloza, L. and Venkatesh, A. (2006), "Further evolving the new dominant logic of marketing: from services to the social construction of markets", Marketing Theory, Vol. 6 No. 3, pp. 299-316.

Pohlmann, A. and Kaartemo, V. (2017), "Research trajectories of Service-Dominant Logic: emergent themes of a unifying paradigm in business and management", Industrial Marketing Management, Vol. 63, pp. 53-68.

Prahalad, C.K. and Ramaswamy, V. (2003), "The new frontier of experience innovation”, MIT Sloan Management Review, Vol. 44 No. 4, pp. 12-18.

Prahalad, C.K. and Ramaswamy, V. (2004), The Future of Competition: Co-creating Unique Value with Customers, Harvard Business Press, Boston, MA.

Ranaweera, C. and Sigala, M. (2015), "From service quality to service theory and practice", Journal of Service Theory and Practice, Vol. 25 No. 1, pp. 2-9.

Randall, W.S., Wittmann, C.M., Nowicki, D.R. and Pohlen, T.L. (2014), "Service-dominant logic and supply chain management: are we there yet?", International Journal of Physical Distribution and Logistics Management, Vol. 44 Nos 1/2, pp. 113-131.

Ranjan, K.R. and Read, S. (2016), "Value co-creation: concept and measurement", Journal of the Academy of Marketing Science, Vol. 44 No. 3, pp. 290-315.

Riivits-Arkonsuo, I. and Leppiman, A. (2015), "Young consumers and their brand love", International Journal of Business and Social Research, Vol. 5 No. 10, pp. 3-44.

Roberts, D., Hughes, M. and Kertbo, K. (2014), "Exploring consumers' motivations to engage in innovation through co-creation activities", European Journal of Marketing, Vol. 48 Nos 1/2, pp. $147-169$.

Rousselet, E., Brial, B., Cadario, R. and Béji-Bécheur, A. (2018), "Moral intensity, issue characteristics, and ethical issue recognition in sales situations", Journal of Business Ethics, Vol. 163, pp. 347-363. 
Rumbold, K. (2010), "From "access" to "creativity": shakespeare institutions, new media, and the language of cultural value", Shakespeare Quarterly, Vol. 61 No. 3, pp. 313-336.

Saarijärvi, H., Puustinen, P., Yrjölä, M. and Mäenpää, K. (2017), "Service-dominant logic and service logic-contradictory and/or complementary?”, International Journal of Services Sciences, Vol. 6 No. 1, pp. 1-25.

Santala, M. and Parvinen, P. (2007), "From strategic fit to customer fit", Management Decision, Vol. 45 No. 3, pp. 582-601.

Saragih, H.S. and Tan, J.D. (2018), "Co-innovation: a review and conceptual framework”, International Journal of Business Innovation and Research, Vol. 17 No. 3, pp. 361-377.

Saunila, M., Rantala, T. and Ukko, J. (2017), "Characteristics of customer value creation in digital services”, Journal of Service Science Research, Vol. 9 No. 2, pp. 239-258.

Schembri, S. (2006), "Rationalizing service logic, or understanding services as experience?", Marketing Theory, Vol. 6 No. 3, pp. 381-392.

Schor, J. (2014), "Debating the sharing economy", Journal of Self-Governance and Management Economics, Vol. 4 No. 3, pp. 7-22.

Schutjens, V.A.J.M. and Wever, E. (2000), "Determinants of new firm success", Papers in Regional Science, Vol. 79, pp. 135-159.

Sesselmann, J. (2015), Empowering Brands with Customer Integration: Classification, Benefits and Success Factors, Springer Gabler, Berlin.

Shamim, A., Ghazali, Z. and Albinsson, P.A. (2016), "An integrated model of corporate brand experience and customer value co-creation behaviour", International Journal of Retail and Distribution Management, Vol. 44 No. 2, pp. 139-158.

Shaw, E.H. and Jones, D.B. (2005), "A history of schools of marketing thought”, Marketing Theory, Vol. 5 No. 3, pp. 239-281.

Sherif, C.W., Sherif, M. and Nebergall, R.E. (1965), Attitude and Attitude Change: The Social JudgmentInvolvement Approach, Saunders, London.

Sichtmann, C., Selasinsky, M.V. and Diamantopoulos, A. (2011), "Service quality and export performance of business-to-business service providers: the role of service employee-and customer-oriented quality control initiatives", Journal of International Marketing, Vol. 19 No. 1, pp. 1-22.

Sieweke, J. (2014), "Pierre Bourdieu in management and organization studies-a citation context analysis and discussion of contributions", Scandinavian Journal of Management, Vol. 30 No. 4, pp. 532-543.

Siltaloppi, J., Koskela-Huotari, K. and Vargo, S.L. (2016), "Institutional complexity as a driver for innovation in service ecosystems", Service Science, Vol. 8 No. 3, pp. 333-343.

Simmonds, H. and Gazley, A. (2018), "Service ecotones: the complex boundary zones of service (eco) systems", Journal of Service Theory and Practice, Vol. 28 No. 3, pp. 384-404.

Skålén, P., Aal, K.A. and Edvardsson, B. (2015), "Cocreating the Arab spring: understanding transformation of service systems in contention", Journal of Service Research, Vol. 18 No. 3, pp. 250-264.

Smith, L., Ng, I. and Maull, R. (2012), "The three value proposition cycles of equipment-based service", Production Planning and Control, Vol. 23 No. 7, pp. 553-570.

Spohrer, J. and Maglio, P.P. (2010), "Service science: toward a smarter planet", in Salvendy, G. and Karwowski, W. (Eds), Introduction to Service Engineering, John Wiley \& Sons, Hoboken, NJ, pp. 3-30.

Storbacka, K., Frow, P., Nenonen, S. and Payne, A. (2012), "Designing business models for value co-creation", Review of Marketing Research, Vol. 9 No. 2012, pp. 51-78.
15 years of servicedominant logic 
JSTP 31,4

Strandvik, T., Heinonen, K. and Vollmer, S. (2019), "Revealing business customers' hidden value formation in service”, Journal of Business and Industrial Marketing, Vol. 34 No. 6, pp. 1145-115.

Tahamtan, I. and Bornmann, L. (2018), "Core elements in the process of citing publications: conceptual overview of the literature", Journal of Informetrics, Vol. 12 No. 1, pp. 203-216.

Tollin, K. and Schmidt, M. (2012), "Marketing logics, ambidexterity and influence", Journal of Strategic Marketing, Vol. 20 No. 6, pp. 509-534.

Tronvoll, B. (2007), "Customer complaint behaviour from the perspective of the service-dominant logic of marketing", Managing Service Quality, Vol. 17 No. 6, pp. 601-620.

Tronvoll, B. (2012), "A dynamic model of customer complaining behaviour from the perspective of service-dominant logic", European Journal of Marketing, Vol. 46 Nos 1/2, pp. 284-305.

Truong, Y., Simmons, G. and Palmer, M. (2012), "Reciprocal value propositions in practice: constraints in digital markets", Industrial Marketing Management, Vol. 41 No. 1, pp. 197-206.

Tynan, C. and McKechnie, S. (2009), "Experience marketing: a review and reassessment", Journal of Marketing Management, Vol. 25 Nos 5-6, pp. 501-517.

Vargo, S.L. (2011), "Market systems, stakeholders and value propositions: toward a service-dominant logic-based theory of the market”, European Journal of Marketing, Vol. 45 Nos 1/2, pp. 217-222.

Vargo, S.L. and Akaka, M.A. (2009), "Service-dominant logic as a foundation for service science: clarifications", Service Science, Vol. 1 No. 1, pp. 32-41.

Vargo, S.L. and Akaka, M.A. (2012), "Value cocreation and service systems (re) formation: a service ecosystems view”, Service Science, Vol. 4 No. 3, pp. 207-217.

Vargo, S.L. and Lusch, R.F. (2004), "Evolving to a new dominant logic for marketing", Journal of Marketing, Vol. 68 No. 1, pp. 1-17.

Vargo, S.L. and Lusch, R.F. (2006), "Service-dominant logic", in The Service-Dominant Logic of Marketing: Dialog, Debate, and Directions, M.E. Sharpe, Armonk, New York.

Vargo, S.L. and Lusch, R.F. (2008a), "Service-dominant logic: continuing the evolution", Journal of the Academy of Marketing Science, Vol. 36 No. 1, pp. 1-10.

Vargo, S.L. and Lusch, R.F. (2008b), "Why "service”?", Journal of the Academy of Marketing Science, Vol. 36 No. 1, pp. 25-38.

Vargo, S.L. and Lusch, R.F. (2011a), "It's all B2B. . . and beyond: toward a systems perspective of the market”, Industrial Marketing Management, Vol. 40 No. 2, pp. 181-187.

Vargo, S.L. and Lusch, R.F. (2011b), "Stepping aside and moving on: a rejoinder to a rejoinder", European Journal of Marketing, Vol. 45 Nos 7/8, pp. 1319-1321.

Vargo, S.L. and Lusch, R.F. (2014), "Inversions of service-dominant logic", Marketing Theory, Vol. 14 No. 3, pp. 239-248.

Vargo, S.L. and Lusch, R.F. (2016), "Institutions and axioms: an extension and update of servicedominant logic", Journal of the Academy of Marketing Science, Vol. 44 No. 1, pp. 5-23.

Vargo, S.L. and Lusch, R.F. (2017), "Service-dominant logic 2025", International Journal of Research in Marketing, Vol. 34 No. 1, pp. 46-67.

Vargo, S.L. and Lusch, R.F. (2018), The SAGE Handbook of Service-Dominant Logic, SAGE, Los Angeles.

Vargo, S.L., Maglio, P.P. and Akaka, M.A. (2008), "On value and value co-creation: a service systems and service logic perspective”, European Management Journal, Vol. 26 No. 3, pp. 145-152.

Vargo, S.L., Lusch, R.F. and Akaka, M.A. (2010), "Advancing service science with service-dominant logic", in Maglio, P., Kieliszewski, C.A. and Spohrer, J.C. (Eds), Handbook of Service Science. Service Science: Research and Innovations in the Service Economy, Springer, Boston, MA, pp. 133-156.

Vargo, S.L., Wieland, H. and Akaka, M.A. (2015), "Innovation through institutionalization: a service ecosystems perspective”, Industrial Marketing Management, Vol. 44, pp. 63-72. 
Vendrell-Herrero, F., Gomes, E., Collinson, S., Parry, G. and Bustinza, O.F. (2018), "Selling digital services abroad: how do extrinsic attributes influence foreign consumers' purchase intentions?", International Business Review, Vol. 27 No. 1, pp. 173-185.

Verhoef, P.C., Stephen, A.T., Kannan, P.K., Luo, X., Abhishek, V., Andrews, M., Bart, Y., Datta, H., Fong, N., Hoffman, D.L., Hu, M.M., Novak, T., Rand, W. and Zhang, Y. (2017), "Consumer connectivity in a complex, technology-enabled, and mobile-oriented world with smart products", Journal of Interactive Marketing, Vol. 40, pp. 1-8.

Voos, H. and Dagaev, K.S. (1976), “Are all citations equal? Or, did we op. Cit. Your idem?”, Journal of Academic Librarianship, Vol. 1 No. 6, pp. 19-21.

Wang, K. (2015), "Determinants of mobile value-added service continuance: the mediating role of service experience", Information and Management, Vol. 52 No. 3, pp. 261-274.

Weitzl, W. and Einwiller, S. (2018), "Consumer engagement in the digital era its nature, drivers, and outcomes", in The Handbook of Communication Engagement, pp. 453-473.

White, M.D. and Wang, P. (1997), "A qualitative study of citing behavior: contributions, criteria, and metalevel documentation concerns", The Library Quarterly, Vol. 67 No. 2, pp. 122-154.

Wieland, H., Polese, F., Vargo, S.L. and Lusch, R.F. (2012), “Toward a service (eco) systems perspective on value creation", International Journal of Service Science, Management, Engineering, and Technology, Vol. 3 No. 3, pp. 12-25.

Wieland, H., Hartmann, N.N. and Vargo, S.L. (2017), "Business models as service strategy", Journal of the Academy of Marketing Science, Vol. 45 No. 6, pp. 925-943.

Wikhamn, B.R., Ljungberg, J. and Styhre, A. (2013), "Enacting hard and soft product offerings in mature industries: moving towards servitisation in Volvo", International Journal of Innovation Management, Vol. 17 No. 4, p. 1350014.

Wilden, R., Akaka, M.A., Karpen, I.O. and Hohberger, J. (2017), "The evolution and prospects of service-dominant logic: an investigation of past, present, and future research", Journal of Service Research, Vol. 20 No. 4, pp. 345-361.

Wilkie, W. and Moore, E.S. (2006), "Examining marketing scholarship and the service-dominant logic", in Lusch, R.F. and Vargo, S.L. (Eds), The Service-Dominant Logic for Marketing: Dialog, Debate, and Directions, New York and London, pp. 266-278.

Williams, J. (2012), "The logical structure of the service-dominant logic of marketing", Marketing Theory, Vol. 12 No. 4, pp. 471-483.

Windahl, C., Karpen, I.O. and Wright, M.R. (2020), "Strategic design: orchestrating and leveraging market-shaping capabilities", Journal of Business and Industrial Marketing, Vol. 35 No. 9, pp. 1413-1424.

Wirtz, J., Patterson, P.G., Kunz, W.H., Gruber, T., Lu, V.N., Paluch, S. and Martins, A. (2018), "Brave new world: service robots in the frontline", Journal of Service Management, Vol. 29 No. 5, pp. 907-931.

Xu, Y., Marshall, R., Edvardsson, B. and Tronvoll, B. (2014), "Show you care: initiating co-creation in service recovery", Journal of Service Management, Vol. 25 No. 3, pp. 369-387.

Zaborek, P. and Mazur, J. (2017), "Exploring links between engaging customers in value co-creation and product innovativeness", International Journal of Management and Economics, Vol. 53 No. 3, pp. 82-106.

Zhao, D. and Strotmann, A. (2014), "In-text author citation analysis: feasibility, benefits, and limitations", Journal of the Association for Information Science and Technology, Vol. 65 No. 11, pp. 2348-2358.

\section{About the authors}

Marco Tregua (Ph.D. in Business Economics, University of Naples Federico II) is Assistant Professor in International Business Management at University Federico II of Naples, Italy. His research interests include innovation in its different literature perspectives, sustainability in management and service
15 years of servicedominant logic 
JSTP

31,4

606 logic. He co-authored articles published in the Journal of Service Theory and Practice, Sustainability Science, and Journal of Business Ethics, among others.

Danilo Brozovic (Ph.D. in Business Administration, Stockholm Business School) is Senior Lecturer in Business Administration at the University of Skövde, Sweden. His research interests include service marketing, strategic flexibility, and the intersection between the topics. His work has appeared in the Journal of Service Theory and Practice, International Journal of Management Reviews, Business Strategy and the Environment, British Journal of Management, and Journal of Services Marketing, among others. Danilo Brozovic is the corresponding author and can be contacted at: danilo.brozovic@his.se

Anna D'Auria (Ph.D. in Tourism Management, University of Naples Federico II) is Research Fellow at University of Naples Federico II and Lecturer in Marketing and Management at Universidad de Jaén in Spain. Her main areas of interest are tourism and destination management, smart innovation, sustainability, and service theories. She authored and co-authored articles published in Sustainability Science, International Journal of Public Sector Management, and International Journal of Innovation and Technology Management, among others.

For instructions on how to order reprints of this article, please visit our website: www.emeraldgrouppublishing.com/licensing/reprints.htm Or contact us for further details: permissions@emeraldinsight.com 